\title{
Biomineralization of Carbonate Minerals Induced by the Halophilic Chromohalobacter israelensis under High Salt Concentrations: Implications for Natural Environments
}

\author{
Zuozhen Han ${ }^{1,2, *,+}$, Dan Li ${ }^{1,+}$, Hui Zhao ${ }^{2,3,+}$, Huaxiao Yan ${ }^{2,3, *}$ and Peiyuan Li $^{1}$ \\ 1 Shandong Provincial Key Laboratory of Depositional Mineralization and Sedimentary minerals, College of \\ Earth Science and Engineering, 266590 Qingdao, China \\ 2 Key Laboratory of Marine Geology and Environment, Chinese Academy of Sciences, 266071 Qingdao, \\ China \\ 3 Department of Bioengineering, College of Chemical and Environmental Engineering, Shandong University \\ of Science and Technology, 266590 Qingdao, China \\ * Correspondence: Zuozhen Han: hanzuozhen65@126.com \\ Huaxiao Yan: 15954804511@163.com \\ † Zuozhen Han, Dan Li and Hui Zhao contributed equally to this paper and were considered as co-first \\ authors.
}

\begin{abstract}
The mechanism underlying microbiologically induced carbonate precipitation have not been thoroughly characterized, although numerous scholars and experts have specifically investigated questions regarding minerals induced by bacteria. The study of the precipitation of carbonate minerals induced by halophilic bacteria has aroused wide concern. The present study aimed to investigate the characterization and process of biomineralization in high salt systems by a halophilic bacterium, Chromohalobacter israelensis strain LD532 (GenBank: KX766026), which was isolated from the Yinjiashan Saltern in China. Carbonate minerals induced by LD532 were investigated in several sets of comparative experiments that employed magnesium sulfate and magnesium chloride as Mg resources. Magnesium calcite and aragonite were induced by LD532 bacteria, whereas these minerals did not appear in the control group. The mineral phases, micromorphologies, and crystal structures were analysed using X-ray powder diffraction, scanning electron microscopy, and energy dispersive $\mathrm{X}$-ray detection. The carbonic anhydrase and urease secreted by strain LD532 through metabolism increased the $\mathrm{pH}$ value of the liquid medium and promoted the process of carbonate precipitation. Further study using high resolution transmission electron microscopy, energy dispersive X-ray detection and analysis of ultrathin slices showed that the nucleation sites of carbonate minerals were located on extracellular polymeric substances and the membranes of intracellular vesicles of LD532 bacteria, which provided favourable conditions for the growth of carbonate mineral crystals. The morphologies and compositions of minerals formed in solutions of $\mathrm{MgSO}_{4}$ and $\mathrm{MgCl}_{2}$ display significant differences, indicating that different sources of $\mathrm{Mg}^{2+}$ may also affect the physiological and biochemical activities of microorganisms and thus mineral deposition. This study will be of some interest for the interpretation of carbonate biomineralization in natural salt environments and has some value as a reference in understanding sedimentary carbonates in ancient marine environments, such as tidal flats.
\end{abstract}

Keywords: biomineralization; halophilic bacteria; precipitation; carbonate minerals; $\mathrm{Mg} / \mathrm{Ca}$ ratios; nucleation sites 


\section{Introduction}

Carbonate minerals are widely distributed in the earth's crust and play an important role in the study of early diagenesis of marine sediments, calcification and the formation of cavernous chemical deposits [1]. In recent decades, many microbial fossils, such as those of cyanobacteria, have been discovered in bioliths, which confirms that microbes are closely associated with the diagenesis of minerals. Many researchers have investigated the ability of bacteria to precipitate minerals in natural environments and the laboratory, based on previous research findings on bioliths, such as stromatolites, oncolites, dendrites, and thrombolites [2-10]. Therefore, the role of microorganisms in the precipitation of a wide variety of carbonates has been generally acknowledged in recent years [11]. Interactions between microorganisms and minerals are a type of geological activity that occurs widely in natural environments, and mineral dissolution and precipitation are almost inseparable from the role of microorganisms. Microbial mineralization can be traced back to distant geological times. For example, the development of large-scale stromatolites and iron-rich formations occurred during the Precambrian. Therefore, carbonate precipitation induced by different species of bacteria was a very common event in natural environments [5]. The changes in aragonite saturation in seawater induced by the bloom-forming filamentous diazotroph Trichodesmium under different levels of phosphorus (P) availability have been described [12]. The morphology and mineralogy of carbonate minerals can be influenced by sulfate-reducing bacteria, which can produce copious amounts of extracellular polymeric substances (EPS) and increase the alkalinity by sulfate reduction and consumption of organic acids [13,14]. Many researchers have studied the formation of calcite crystals on EPS secreted by Bacillus firmus, Bacillus sphaericu and Synechocystis sp. PCC6803 [15,16,17].

In addition, the precipitation mechanisms of minerals have been further studied in the process of biomineralization. Some researchers have argued that bacteria can induce the formation of different types of carbonates under appropriate conditions [18]. The precipitation of carbonates and other types of minerals by biomineralization is caused by the participation of specific macromolecules originating from bacteria in the culture medium [19]. The activity of urease and carbonic anhydrase (CA) plays an important role in microbiologically induced carbonate precipitation [20,21]. The mineralization mechanism of Bacillus has also been studied in the process of carbonate calcification [22]. However, controversies still exist regarding the specific role that different bacteria play in the formation process of microbial carbonates in many cases $[2,23,24]$, and the optimal conditions for biomineralization require further investigation [7].

Researchers have suggested that the composition and ionic concentration of the solution exert a considerable influence on mineral precipitation in geological environments and have shown that acicular high-Mg calcite or aragonite can be produced in seawater with a high $\mathrm{Mg} / \mathrm{Ca}$ ratio or in high-salinity lakes [25]. The element $\mathrm{Mg}$ is involved in almost all of the geochemical processes relative to the formation of carbonate rocks, especially dolomite [26]. Calcite mineralization can be controlled by the $\mathrm{Mg} / \mathrm{Ca}$ ratio of seawater [27]. $\mathrm{Ca}, \mathrm{Mg}$ and $\mathrm{Mg} / \mathrm{Ca}$ ratios have an effect on the precipitation of $\mathrm{Mg}$-rich carbonates [28]. The concentration of $\mathrm{Mg}^{2+}$ has some influence on the structure of monohydrocalcite during its formation process [29].

In recent years, the precipitation of carbonates induced by halophilic bacteria has been an important topic of research. Moderately halophilic bacteria are those that grow optimally at salt concentrations of $3 \%$ to $15 \%(\mathrm{w} / \mathrm{v})$. Halophiles can survive under high-salt conditions because of their special cellular structure and metabolic mechanism. In previous studies, several researchers have observed different minerals produced by halophilic bacteria under different conditions. A moderately halophilic bacterium, Chromohalobacter marismortui, which was isolated from the Dead Sea in 1940 by Elazari Volcani has been described [30], and the precipitation of minerals by microorganisms was studied for the first time using Chromohalobacter marismortui [7]. The carbonate precipitation induced by Halomonas Mónica has been studied under different salt concentrations and incubation conditions, and the mineral phases produced were analyzed [5,31]. The mechanism of mineralization induced by halophilic bacteria has also been studied by a number of researchers. The cellular envelopes of bacteria provided nucleation sites in the process of carbonate precipitation [5- 
8,10,28]. The EPS and the cell walls were identified as the nucleation sites [32]. Meanwhile, the activity of CA was related to the formation of minerals [31]. Based on the studies mentioned above, it can be seen that the mechanism underlying microbiologically induced carbonate precipitation has not been thoroughly characterized, although numerous scholars and experts have specifically investigated questions regarding minerals induced by bacteria. Therefore, the mechanism of biomineralization still requires in-depth exploration.

In this paper, the precipitation of carbonate induced by the bacterium Chromohalobacter israelensis LD532, which was isolated from the Yinjiashan Saltern in China, was studied under conditions including high-salt $(\mathrm{NaCl})$ concentrations, varying $\mathrm{Mg} / \mathrm{Ca}$ ratios $(0,2,4,6,8$, and 10$)$ and differing $\mathrm{Mg}^{2+}$ sources. The experimental groups were inoculated with $1 \%$ of $C$. israelensis LD532 bacterial liquid seed, and the control groups were inoculated with the same volume of sterile distilled water. X-ray diffraction (XRD), scanning electron microscopy (SEM) and energy dispersive $X$-ray detection (EDS) were used to study the mineralogy and morphology of the carbonate crystals induced by $C$. israelensis LD532 bacteria. The organic functional groups originating from LD532 bacteria in carbonate minerals were analyzed using Fourier transform infrared spectroscopy (FTIR). High-resolution transmission electron microscopy (HRTEM), selected area electron diffraction (SAED) and energy dispersive spectrometry (EDS) were used to analyze the morphology and the elemental compositions of mineral crystals found on the EPS of C. israelensis LD532 bacteria. To further determine the nucleation sites of carbonate minerals, ultra-thin slices of $C$. israelensis LD532 bacteria in $\mathrm{MgSO}_{4}$ and $\mathrm{MgCl}_{2}$ culture media were prepared and observed using TEM. Carbonic anhydrase (CA) and urease were also investigated in order to further explore the mechanism of microbially induced carbonate minerals. The study of carbonate biomineralization processes provides a reference for interpreting the formation mechanisms of carbonate minerals in the geological record, is beneficial in understanding microbial mineralization in natural and laboratory environments, and also helps to explain the origins of ancient carbonate sedimentary environments.

\section{Materials and Methods}

\subsection{Culture Media}

A liquid enrichment culture medium with the following composition was used: (in $\mathrm{g} \mathrm{L}^{-1}$ deionized water) beef extract 5.0, tryptone 10.0 , and $\mathrm{NaCl} 150$. The $\mathrm{pH}$ of the culture medium was 7.2. The solid medium was added $20 \mathrm{~g} \mathrm{~L}^{-1}$ agar based on the above liquid medium. The above culture medium was also used to isolate and purify the halophilic bacteria.

2.2. Isolation and Identification of Bacterium C. israelensis LD532

LD532 bacteria were isolated from water samples collected from the Yinjiashan Saltern $\left(35^{\circ} 48^{\prime} \mathrm{N}, 119^{\circ} 55^{\prime} \mathrm{E}\right)$ in Qingdao, China. The water samples were introduced into the liquid enrichment medium at an inoculation volume of $1 \%$ and incubated at $130 \mathrm{rpm}$ and $30{ }^{\circ} \mathrm{C}$ in a constant temperature shaker (HZQ-F160, Harbin Donglian Electronic Technology Development Co., Ltd, China). The medium turned turbid after 2 days of culture, indicating that several dominant types of halophilic bacteria were present. The change in transparency was mainly attributable to the physiological and biochemical activities of the halophilic bacteria. The turbid enrichment medium was diluted 1,000-fold using sterile distilled water, and the diluent was spread evenly over the surface of the solid medium for further isolation and purification. All of the bacterial cultures were incubated at $30{ }^{\circ} \mathrm{C}$ in an electrothermal constant temperature incubator (DHP-9050B, Shanghai Langgan Laboratory Equipment Co., Ltd, China) until single colonies could be seen by the naked eye. A single bacterial colony was then selected and purified an additional 3 times. A pure strain named LD532, was obtained and then identified by physiological and biochemical identification and $16 \mathrm{~S}$ rDNA identification [33].

Bacterial genomic DNA was extracted with the improved cetyltrimethylammonium bromide (CTAB) method [34] and used as a template for PCR. The 16S rDNA gene sequences were amplified with universal primers 27F (5'-agagtttgatcatggctcag-3') and 1492R (5'- tacggttaccttgttacgactt-3') [35]. The PCR products were then analysed via agarose gel electrophoresis. The gene fragments that were approximately $1500 \mathrm{bp}$ long in the agarose gel were the expected products. The PCR products were sequenced by Shanghai Sangon Biotech Co., Ltd. The complete DNA sequence was obtained 
through fragment assembly using DNAMAN 8.0 software. Subsequently, a nucleotide homology comparison was carried out using the Basic Local Alignment Search Tool (BLAST) software package. The phylogenetic tree of LD532 was constructed using MEGA 5.0 software with a neighbour-joining method [36]. The $16 \mathrm{~S}$ rDNA sequence of $C$. israelensis LD532 has been deposited in GenBank under accession number KX766026.

\subsection{Morphology of C. israelensis LD532 Bacteria}

After 10 days of incubation at $30^{\circ} \mathrm{C}$, a single colony on the surface of the solid medium with a diameter of approximately $5 \mathrm{~mm}$ was transferred to a $1.5-\mathrm{mL}$ centrifuge tube and diluted with 200 $\mu \mathrm{L}$ of distilled water. The above diluent was dripped onto a copper grid before being analysed by TEM (JEM-2100, Japan Electronics Company, JEOL, Japan) after natural drying.

2.4. Growth of C. israelensis LD532 Bacteria at Different $\mathrm{NaCl}$ Concentrations and $\mathrm{pH}$ Values

The growth curve of LD532 bacteria in the liquid culture medium was determined. The composition of the liquid medium was as follows: (in $\mathrm{g} \mathrm{L}^{-1}$ deionized water) beef extract 5.0, tryptone 10.0, and $\mathrm{NaCl} 100.0$. The $\mathrm{pH}$ of the liquid medium was 7.2. The concentration of LD532 bacteria was measured using a spectrophotometer (722s, Shanghai Precision and Scientific Instrument Corporation, China) at $600 \mathrm{~nm}$. At the same time, the fermentation liquid was used as liquid seed when the value measured with the spectrophotometer at $600 \mathrm{~nm}$ was approximately 0.9 .

The growth of LD532 bacteria under different salt $(\mathrm{NaCl})$ concentrations was studied. The concentrations of $\mathrm{NaCl}$ were set to $3,5,8,10,12,15,18$, and $20 \%(\mathrm{w} / \mathrm{v})$. The above liquid seed was inoculated into the liquid culture medium with different concentrations of $\mathrm{NaCl}$ at an inoculation volume of $1 \%$ and incubated at $130 \mathrm{rpm}$ and $30^{\circ} \mathrm{C}$. After $24 \mathrm{~h}$, the concentration of LD532 bacteria was measured with the spectrophotometer at $600 \mathrm{~nm}$.

The growth of LD532 bacteria under different $\mathrm{pH}$ values was also studied. The $\mathrm{pH}$ value of the above liquid medium was adjusted to 5.0, 5.5, 6.0, 6.5, 7.0, 7.5, 8.0, 8.5, 9.0 and 9.5. The concentration of LD532 bacteria was measured with the spectrophotometer at $600 \mathrm{~nm}$ after $24 \mathrm{~h}$.

2.5. Growth and $p H$ Curves of LD532 Bacteria at Different $\mathrm{Mg} / \mathrm{Ca}$ Molar Ratios

The growth and $\mathrm{pH}$ curves of LD532 bacteria at different $\mathrm{Mg} / \mathrm{Ca}$ ratios were studied. The concentration of the $\mathrm{Ca}^{2+}$ stock solution was $0.01 \mathrm{M}$. $\mathrm{MgSO}_{4}(2 \mathrm{M}), \mathrm{MgCl}_{2}(2 \mathrm{M}), \mathrm{Na}_{2} \mathrm{CO}_{3}(2 \mathrm{M})$ and $\mathrm{NaHCO}_{3}(1 \mathrm{M})$ mother liquors were prepared according to the conventional method. The composition of the liquid medium was as follows: (in $\mathrm{g} \mathrm{L}^{-1}$ deionized water) beef extract 5.0, tryptone 10.0, $\mathrm{NaCl} 150.0$. Three millilitres of $\mathrm{Na}_{2} \mathrm{CO}_{3}(2 \mathrm{M})$ and $6 \mathrm{~mL}$ of $\mathrm{NaHCO}_{3}(1 \mathrm{M})$ were added to each conical flask containing $150 \mathrm{~mL}$ of the culture medium, and the $\mathrm{pH}$ was adjusted to 7.3 . The different $\mathrm{Mg} / \mathrm{Ca}$ ratios were set as $0,2,4,6,8$, and 10, and each concentration gradient was established for three control groups and three experimental groups. All of the cultures were incubated at $130 \mathrm{rpm}$ and $30{ }^{\circ} \mathrm{C}$ in the constant temperature shaker. The concentrations of LD532 bacteria were measured with the spectrophotometer at $600 \mathrm{~nm}$ at different time intervals. The $\mathrm{pH}$ values were measured using a $\mathrm{pH}$ indicator (PHS-3, Jiangsu Jiangfen Instrument and Equipment Company, China) at different time intervals.

\subsection{Determination of CA Activity of C. israelensis LD532 Bacterial in Culture Solution}

To understand the biomineralization mechanism of $C$. israelensis LD532 bacteria, the CA activity of $C$. israelensis LD532 bacteria in the liquid culture medium was examined. CA activity was detected according to the method described by Smith and Ferry [37], and one unit of CA was defined as the amount of enzyme that releases $1 \mu \mathrm{mol}$ of $p$-nitrophenol per minute.

2.7. Characterization of Carbonates Induced by C. israelensis LD532 Bacteria

Precipitates in the control and experimental groups at different $\mathrm{Mg} / \mathrm{Ca}$ molar ratios were transferred from the bottom of the flask to $4-\mathrm{mL}$ centrifuge tubes and left to rest for $10 \mathrm{~min}$. To fully eliminate the bacteria, the supernatants were discarded, and the deposits were washed with distilled water and anhydrous ethanol 3 times each and then dried in air at room temperature.

To identify the mineral phases of the carbonates induced by C. israelensis LD532 at different $\mathrm{Mg} / \mathrm{Ca}$ ratios, the precipitates mentioned above were studied by XRD (D/Max-RC, Rigaku, Japan) using $2 \theta$ angles ranging from $10^{\circ} \mathrm{C}$ to $80^{\circ} \mathrm{C}$, a step size of 0.02 and a count time of $8^{\circ} \mathrm{min}^{-1}$. At the same time, to further determine whether organic functional groups existed in the carbonate 
minerals, the precipitates were also analysed by FTIR (Nicolet 380, Thermo Fisher Scientific Inc., Massachusetts, American) using a scanning range of 4000-400 $\mathrm{cm}^{-1}$.

The shapes, sizes and micromorphologies of the precipitates were also observed. The mineral precipitates in the control and experimental groups were sprayed with platinum (Pt) in vacuum and observed with SEM (Hitachi S-4800, Japan) after they had dried naturally. The elemental composition of the mineral precipitates was analysed using EDS (EDAX, America).

2.8. Minerals on the Surfaces of C. israelensis LD532 Bacteria

To assess whether the minerals had nucleated on the EPS of $C$. israelensis LD532 bacteria, $C$. israelensis LD532 bacterial suspension in the experimental group having a $\mathrm{Mg} / \mathrm{Ca}$ molar ratio of 2 was dripped onto a copper grid and then observed with HRTEM (JEM-2100, Japan) after drying naturally. The crystal structures and elemental composition of the precipitates on the EPS were analysed with SAED and EDS.

2.9. Analysis of Ultra-thin Slices of Chromohalobacter israelensis LD532 Bacteria

The ultra-thin slices of $C$. israelensis LD532 bacterial cells that had been cultivated for 40 days were prepared as follows: $10 \mathrm{~mL}$ of LD532 bacterial fermentation liquid with an $\mathrm{Mg} / \mathrm{Ca}$ molar ratio of 2 was centrifuged at a speed of $3000 \mathrm{rpm}$ for $5 \mathrm{~min}$. The supernatant was discarded, and the deposit was washed 3 times with phosphate buffer $\left(\mathrm{NaH}_{2} \mathrm{PO}_{4} \bullet 2 \mathrm{H}_{2} \mathrm{O} 3.1167 \mathrm{~g} / \mathrm{L}, \mathrm{Na}_{2} \mathrm{HPO}_{4} \bullet 12 \mathrm{H}_{2} \mathrm{O}\right.$ $20.7472 \mathrm{~g} / \mathrm{L}, \mathrm{pH} 7.4$ ) to remove the remaining culture medium. The cells were fixed with $1 \mathrm{~mL}$ of $2.5 \%$ glutaraldehyde and $1 \%$ osmic acid for $1 \mathrm{~h}$ and washed with phosphate buffer 3 times. The cells were then gradually dehydrated by acetone solutions in the following sequence: $30 \%$ (15 min) - $50 \%$ (15 min $)-70 \%$ (15 min $)-80 \%$ (15 min $)-90 \%$ (15 min $)-95 \%$ (15 min $)-100 \%$ (15 min $)-100 \%$ (15 $\mathrm{min})-100 \%$ (15 min). One millilitre of $30 \%$ epoxy resin solution was then added, and the cells were embedded. The completed ultra-thin slices were analysed with TEM (JEM-2100, Japan).

\section{Results}

\subsection{Identification of C. israelensis LD532 Bacteria}

The bacterium C. israelensis LD532, which was isolated after enrichment and purification, is a gram-negative, strictly aerobic, rod-shaped bacterium with a width of approximately 0.5 to $0.8 \mu \mathrm{m}$ and a length of approximately 0.7 to $1.5 \mu \mathrm{m}$ (Table 1, Figure 1a and b). Bacterium LD532 can move in the semisolid medium (Table 1), indicating that the bacteria are motile. Bacteria commonly derive their motility from external structures called flagella. It can be seen from Figure 1a and $b$ that more than one flagellum grows on the surface of bacterium LD532, which also demonstrates its motility (Table 1). The results of physiological and biochemical identifications are shown in Table 1. Triple sugar iron agar, amylase, citrate, EPS, motility and urease tests are positive, the V-P, catalase, sulfureted hydrogen, methyl red, cellulase, and esterase tests are negative.

Table.1 The physiological and biochemical identification results of Chromohalobacter israelensis.

\begin{tabular}{ccc}
\hline Test item & LD532 & Standard Chromohalobacter israelensis \\
\hline Triple Sugar Iron Agar & + & + \\
V-P & - & - \\
Catalase & - & - \\
Sulfureted Hydrogen & - & - \\
Amylase & + & - \\
Methyl Red & - & + \\
Citrate & + & - \\
Cellulase & - & + \\
EPS & + & + \\
Moveability & + & - \\
Esterase & - & + \\
Urease & + & +
\end{tabular}

1. Note: The "-" is negative; the "+" is positive. 

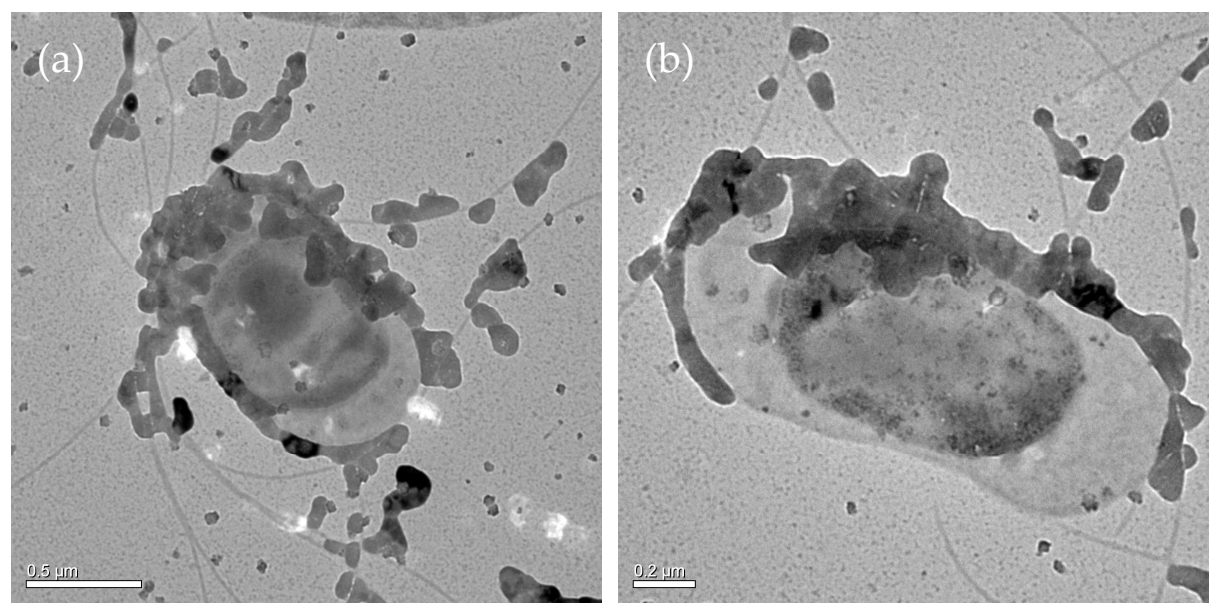

Figure 1. The morphology of LD532 bacteria analyzed by HRTEM.

The $16 \mathrm{~S}$ rDNA sequence length of LD532 was $1452 \mathrm{bp}$, as determined using DNAMAN 8.0 to join complementary sequences. A nucleotide homology comparison was conducted with the BLAST program. A phylogenetic tree was constructed with MEGA 5.0 software using the neighbour-joining method (Figure 2). The full-length 16S rDNA sequence of strain LD532 shared $>97 \%$ nucleotide sequence homology with the $16 \mathrm{~S}$ rDNA sequences of many Chromohalobacter strains in GenBank, and $98 \%$ homology with those of three strains of C. israelensis. The LD532 strain was most closely related to $C$. israelensis on the phylogenetic tree based on 16S rDNA sequences, which was consistent with the physiological and biochemical characteristics of the isolated strain. Thus, strain LD532 was identified as C. israelensis.

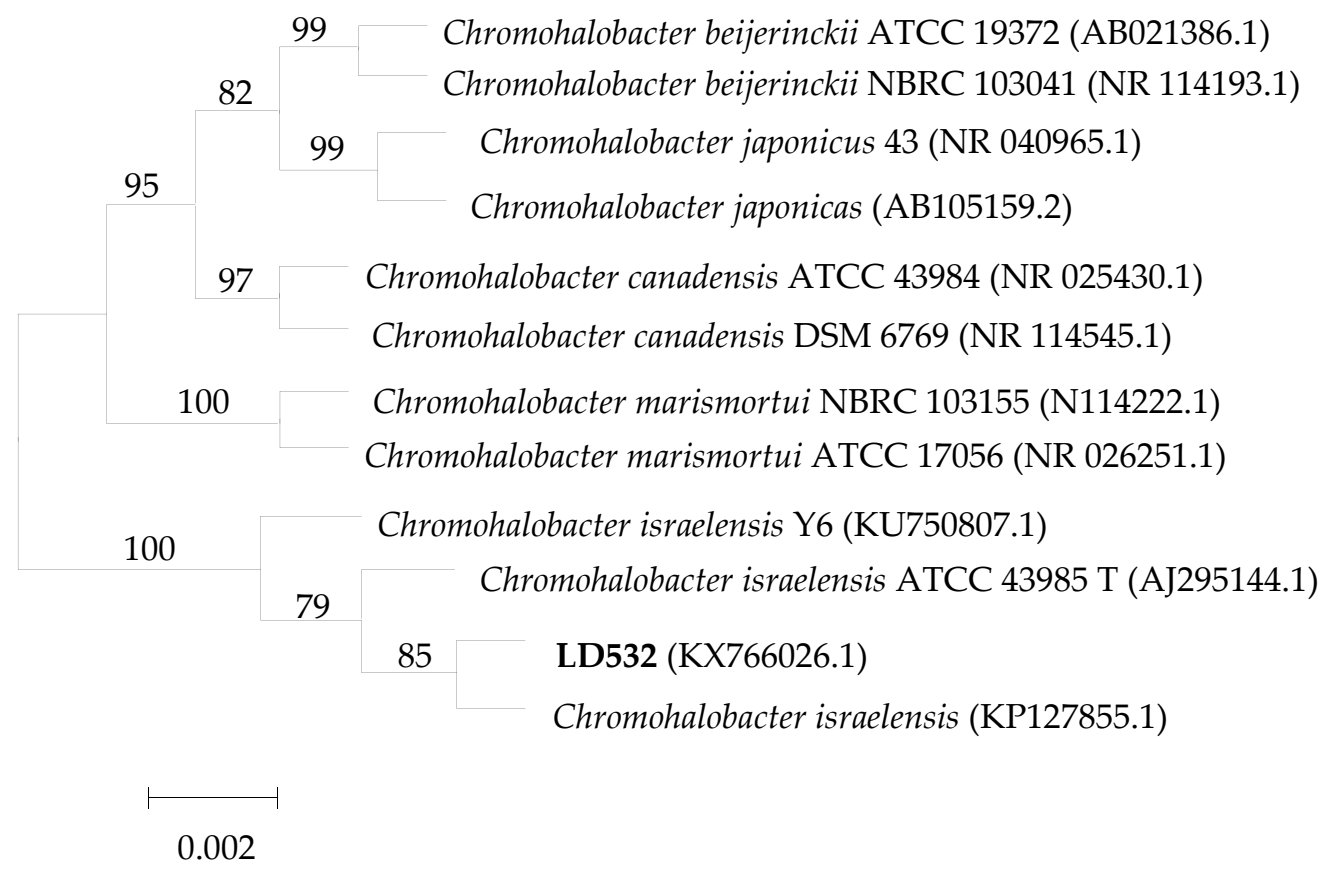

Figure 2. Phylogenetic tree of LD532 bacteria.

3.2. The Growth Curves of C. israelensis LD532 Bacteria in Liquid Culture Medium at Different Salt Concentrations and $\mathrm{pH}$ Values

Figure 3a shows the growth curve of bacterial strain LD532 incubated in the liquid culture medium with a $\mathrm{NaCl}$ concentration of $15 \%(\mathrm{w} / \mathrm{v})$ at $30{ }^{\circ} \mathrm{C}$ for 24 hours. It can be seen that the bacteria grow slowly during the initial $3 \mathrm{~h}$, the cells are in the logarithmic growth stage between 3 $45 \mathrm{~h}$, and after $45 \mathrm{~h}$, the bacterial growth declines. Figure $3 \mathrm{~b}$ shows the growth curve of bacterial strain LD532 incubated in the liquid culture medium with different $\mathrm{NaCl}$ concentrations at $30{ }^{\circ} \mathrm{C}$ for 24 hours, and the results indicate that the bacteria grew best at a $\mathrm{NaCl}$ concentration of $10 \%$ among the investigated $\mathrm{NaCl}$ concentrations ranging from $3 \%$ to $20 \%$. Figure 3c shows the growth curve 
of bacterial strain LD532 incubated in the liquid culture medium with different $\mathrm{pH}$ values and a $\mathrm{NaCl}$ concentration of $15 \%$ at $30^{\circ} \mathrm{C}$ for 24 hours. The result shows that the bacteria grew normally under $\mathrm{pH}$ values ranging from 5.0 to 8.5 , but the cell concentrations declined sharply when the $\mathrm{pH}$ was increased above 8.5, and the bacteria almost stopped growing at $\mathrm{pH}$ values of 9.0 and 9.5. According to the above results, culture conditions such as a liquid culture medium, a $\mathrm{pH}$ of 7.3 , and a $\mathrm{NaCl}$ concentration of $15 \%$ were appropriate for use in the following experiments to assess carbonate precipitation induced by LD532 bacteria.
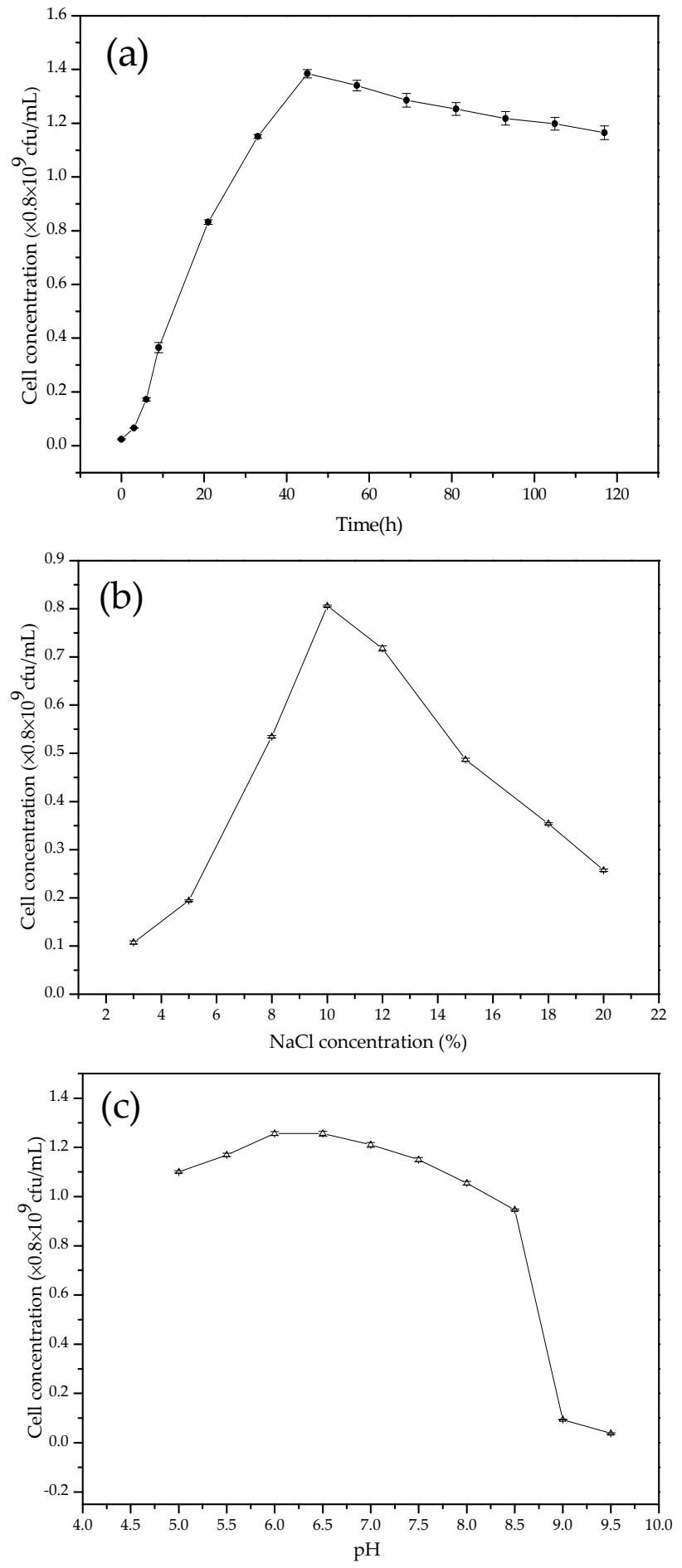

Figure 3. Characterization of LD532 bacteria. (a) growth curve; (b) cell concentration of LD532 bacteria after the $24 \mathrm{hs}^{\prime}$ cultivation at different $\mathrm{NaCl}$ concentrations; (c) cell concentration of LD532 bacteria after the 24hs' cultivation at different $\mathrm{pH}$ values.

3.3. Growth and $\mathrm{pH}$ Curves of LD532 Bacteria at Different $\mathrm{Mg} / \mathrm{Ca}$ Molar Ratios and CA Activity Curve

Figure $4 \mathrm{a}$ shows the growth curves of LD532 bacteria at different $\mathrm{Mg} / \mathrm{Ca}$ ratios and a $\mathrm{NaCl}$ 
concentration of $15 \%$. It can be seen from Figure $4 a$ that, at each $\mathrm{Mg} / \mathrm{Ca}$ ratio $(0,2,4,6,8$, and 10), the bacteria grow slowly during the first $9 \mathrm{~h}$, the cell concentrations increase sharply from $9-50 \mathrm{~h}$ in the logarithmic growth phase, and the bacteria are in a stable phase from $50-100 \mathrm{~h}$. During this last phase, the cell concentrations of LD532 bacteria increase significantly with increasing $\mathrm{Mg} / \mathrm{Ca}$ ratios. According to the above results, it can be seen that, within limits, higher $\mathrm{Mg}^{2+}$ concentrations promoted the growth of LD532 bacteria in this experiment.

To determine the mechanism responsible for the increasing $\mathrm{pH}$ values, the changes in $\mathrm{CA}$ activity were also investigated. Figure $4 \mathrm{~b}$ shows the CA activity curve of bacterial strain LD532 at an $\mathrm{Mg} / \mathrm{Ca}$ ratio of 2 and a $\mathrm{NaCl}$ concentration of $15 \%$. Comparison with Figure 4a shows that $\mathrm{CA}$ was a synchronous synthase because of the coupling of this enzyme with the growth of bacteria. At the beginning, the quantity of CA released is very small. The production of CA increases sharply, from approximately 25 to approximately $300 \mathrm{U} \mathrm{mL}^{-1}$, and accompanies the increase in bacteria during the logarithmic phase. It decreases during the bacterial stable phase and achieves a value of approximately $75 \mathrm{U} \mathrm{mL}^{-1}$ by the end of the experiment.

Figure $4 \mathrm{c}$ shows the $\mathrm{pH}$ curves of LD532 bacteria at different $\mathrm{Mg} / \mathrm{Ca}$ ratios and a $\mathrm{NaCl}$ concentration of $15 \%$. It can be seen from Figure $4 \mathrm{c}$ that the $\mathrm{pH}$ increases sharply, from 7.3 to 8.7, during the first $9 \mathrm{~h}$, due to the release of ammonia from the liquid seed. It declines slowly, from 8.7 to 8.3 , during hours $9-24 \mathrm{~h}$, owing to the release of carbon dioxide produced by the LD532 bacteria. A slight increase in $\mathrm{pH}$, from approximately 8.3 to approximately 8.8 , occurs during $24-60 \mathrm{~h}$. During this period, the concentration of CA secreted by the LD532 bacteria increases from approximately 25 to approximately $300 \mathrm{U} \mathrm{mL}^{-1}$ (Figure $4 \mathrm{~b}$ ), and the $\mathrm{pH}$ values decrease from approximately 8.8 to approximately 8.4 during the period of $60-96$ hours, during which time the $\mathrm{CA}$ activity declines from 300 to $75 \mathrm{U} \mathrm{mL}^{-1}$ (Figure $4 \mathrm{~b}$ ). Finally, the $\mathrm{pH}$ values increase slowly from approximately 8.5 to approximately 9.0 due to the urease activity (Table 1) in the time range of $96-$ $168 \mathrm{~h}$, but it is more notable that the $\mathrm{pH}$ value increases to approximately 8.8 at an $\mathrm{Mg} / \mathrm{Ca}$ ratio of 10 . The values of $\mathrm{pH}$ are stable during the period of time from $168-220 \mathrm{~h}$, approximately $9.0 \mathrm{at} \mathrm{Mg} / \mathrm{Ca}$ ratios of $0,2,4,6$, and 8 , and approximately 8.8 at an $\mathrm{Mg} / \mathrm{Ca}$ ratio of 10 . During the $\mathrm{pH}$-stable phase, the $\mathrm{pH}$ values decrease with increasing $\mathrm{Mg} / \mathrm{Ca}$ ratios, which is closely connected with the fact that, at higher $\mathrm{Mg} / \mathrm{Ca}$ ratios, the higher cell concentrations of LD532 bacteria could produce greater amounts of carbon dioxide. According to the above results, the $\mathrm{pH}$ values could reach approximately 9.0, due to the CA and urease activity, which was taken as a necessary condition for the biomineralization of bacterially induced carbonates.

\subsection{Carbonate Minerals analyzed by XRD and FTIR}

To further analyse the mineral phases and structural characteristics of the precipitates induced by the $C$. israelensis LD532 bacteria, the carbonate precipitates resulting from 15 days of culture were analyzed using XRD. The results of the mineralogical analysis are displayed in Figure 5 and Figure 6.

It can be seen from Figure 5 that the minerals produced in the control and experimental groups containing $\mathrm{MgSO}_{4}$ are calcite at an $\mathrm{Mg} / \mathrm{Ca}$ ratio of 0 (Figure $5 \mathrm{a}$ and $\mathrm{b}$ ), and monohydrocalcite is the only precipitate in the control group at other $\mathrm{Mg} / \mathrm{Ca}$ ratios (Figure $5 \mathrm{a}$ ). In contrast, there is a significant difference in the mineral phases between the control group and the experimental group at an $\mathrm{Mg} / \mathrm{Ca}$ ratio of 2; $\mathrm{Mg}$-calcite, in addition to monohydrocalcite, formed in the experimental group (Figure $5 \mathrm{~b}$ ). The $\mathrm{Mg}$ contents of $\mathrm{Mg}$-calcite were determined to be $27 \%$, by applying the appropriate equation [38,39]. The minerals in the experimental group at other $\mathrm{Mg} / \mathrm{Ca}$ ratios are the same as those in the control group. It is worth noting that, in the control group, the diffraction peak intensity associated with the (222) crystal plane is higher than that of the (411) crystal plane at $\mathrm{Mg} / \mathrm{Ca}$ ratios of 4 and 6 (Figure $5 \mathrm{a}$ ), which contrasts with the standard diffraction peak intensity of monohydrocalcite, indicating that monohydrocalcite with a preferred orientation was precipitated in this experiment.

Figure 6 shows the mineral phases and crystal structures of the precipitates in the control and experimental group containing $\mathrm{MgCl}_{2}$. It can be seen from Figure $6 \mathrm{a}$ that the mineral phase is calcite at an $\mathrm{Mg} / \mathrm{Ca}$ molar ratio of 0 , and it is monohydrocalcite at other $\mathrm{Mg} / \mathrm{Ca}$ molar ratios, consistent 
with the results shown in Figure 5a. A small difference was noted between these two groups, that is, the mineral crystals showed a preferred orientation when $\mathrm{MgSO}_{4}$ was used whereas no such phenomenon was noted in the other group, indicating that the sources of $\mathrm{Mg}^{2+}$ exerted some influence on the crystal structure. It can be seen from Figure $6 \mathrm{~b}$ that the mineral phases are calcite at an $\mathrm{Mg} / \mathrm{Ca}$ ratio of $0, \mathrm{Mg}$-rich calcite (left side of SEM) and aragonite (right side of SEM) at an $\mathrm{Mg} / \mathrm{Ca}$ ratio of 2, and monohydrocalcite at the other $\mathrm{Mg} / \mathrm{Ca}$ ratios. These results indicate that the mineral phases were significantly different from those shown in Figure $5 b$. The above results demonstrate that the source of $\mathrm{Mg}^{2+}$ had an important effect on the newly formed mineral phases and the appearance of preferred orientation.
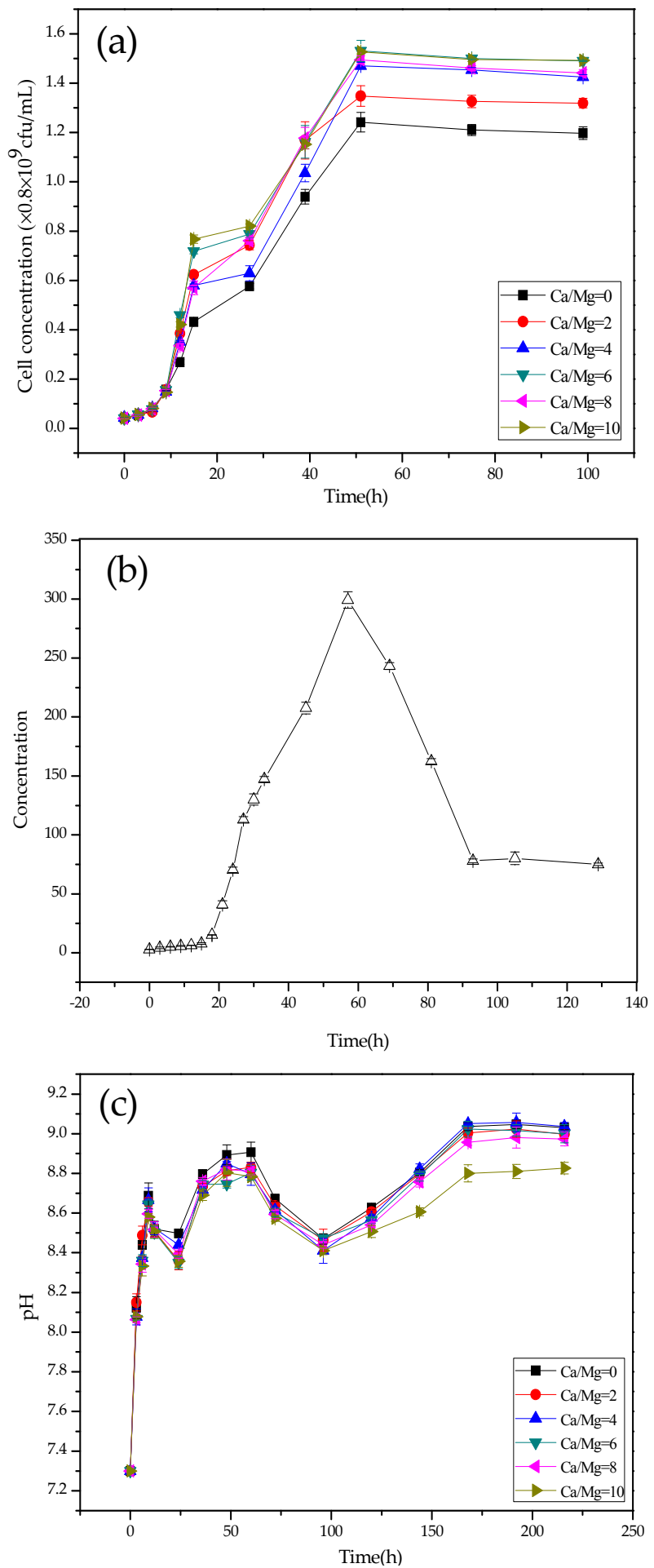

Figure 4. Growth curves, enzyme activity curve and $\mathrm{pH}$ curves of LD532 bacteria at different $\mathrm{Mg} / \mathrm{Ca}$ molar ratios. (a) growth curves; (b) CA activity curve; (c) pH curves. 

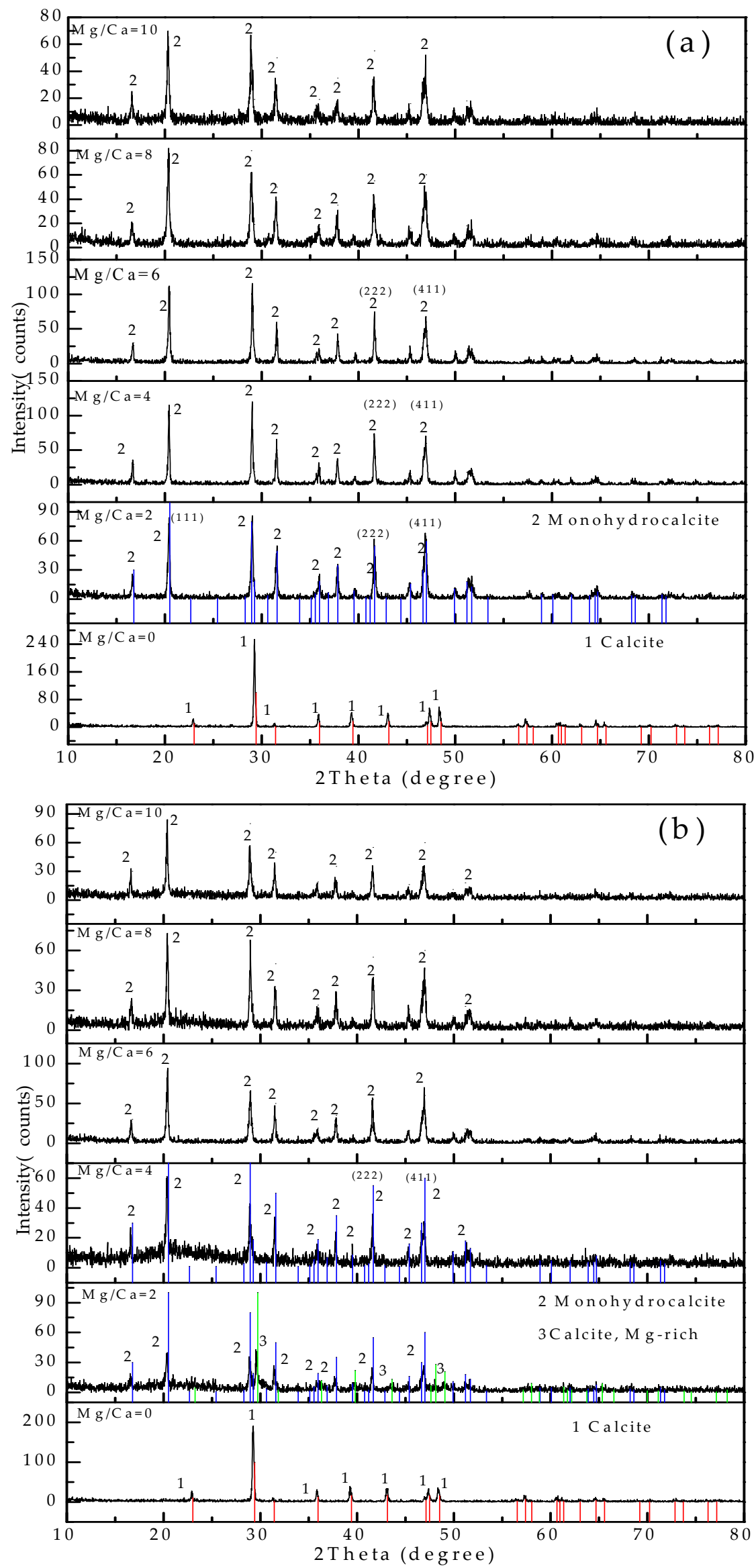

Figure 5. XRD patterns of the minerals at $15 \% \mathrm{NaCl}$ and different $\mathrm{Mg} / \mathrm{Ca}$ molar ratios in aqueous solution of $\mathrm{MgSO}_{4}$ after 15 days of cultivation. (a) the control group; (b) the experimental group. 

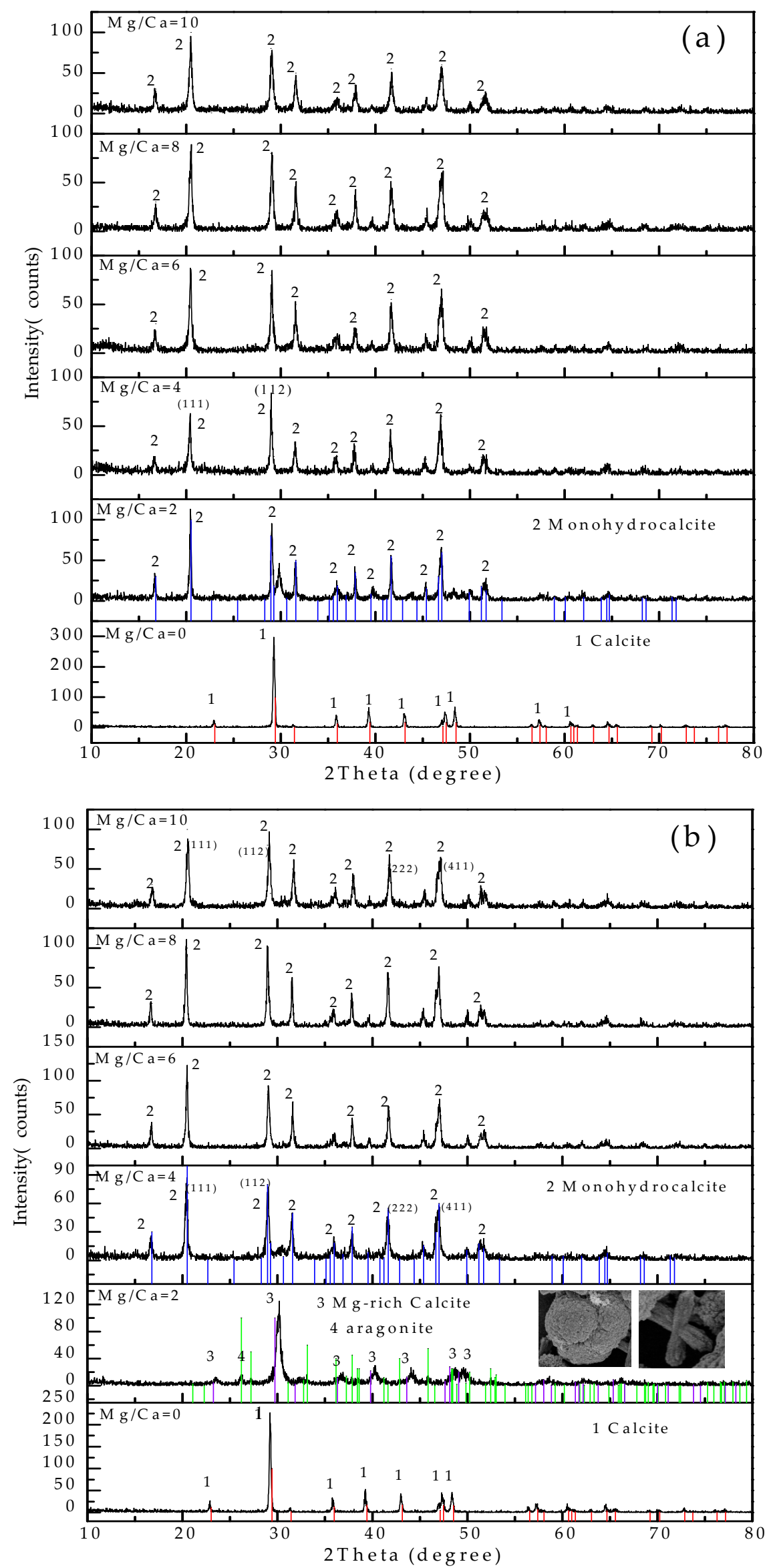

Figure 6. XRD patterns of the minerals at $15 \% \mathrm{NaCl}$ and different $\mathrm{Mg} / \mathrm{Ca}$ molar ratios in $\mathrm{MgCl}_{2}$ aqueous solution after 15 days of cultivation. (a) the control group; (b) the experimental group. 
The FTIR results from the experimental group in $\mathrm{MgCl}_{2}$ solutions with an $\mathrm{Mg} / \mathrm{Ca}$ molar ratio of 2 are shown in Figure 7. The FTIR results for the minerals are displayed in Figure 7a, including the vibrational bands of different types of organic functional groups (marked by the blue arrows) and aragonite (marked by the red arrows). Figure $7 \mathrm{~b}$ shows an enlarged view of the $2800-3000 \mathrm{~cm}^{-1}$ spectral segment of the Figure 7a, where it is seen that C-H methylene vibrational bands $\left(2925 \mathrm{~cm}^{-1}\right)$ and $\mathrm{C}-\mathrm{H}$ methyl vibrational bands $\left(2979 \mathrm{~cm}^{-1}\right)$ are present [40,41], indicating that the organic functional groups were involved in the formation process of these carbonate minerals.
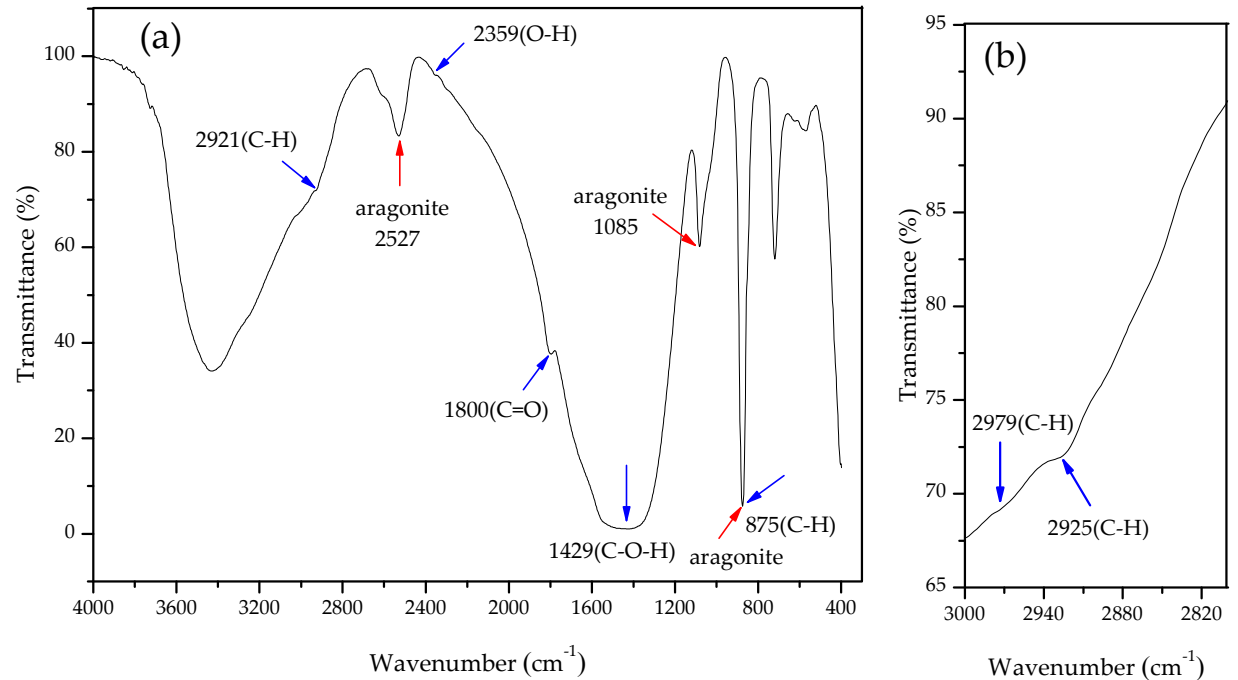

Figure 7. FTIR spectrogram of minerals formed at an $\mathrm{Mg} / \mathrm{Ca}$ molar ratio of 2 in the experimental group containing $\mathrm{MgCl}_{2}$. (a) FTIR spectrogram of minerals from $4000 \mathrm{~cm}^{-1}$ to $400 \mathrm{~cm}^{-1}$; (b) partial enlarged view of the spectrogram from $3000 \mathrm{~cm}^{-1}$ to $2800 \mathrm{~cm}^{-1}$.

\subsection{Carbonate Minerals Analysed by SEM and EDS}

To characterize the micromorphological changes of minerals under different conditions, the precipitates in the control and experimental groups were analyzed using SEM and EDS. The results of the micromorphology analysis of the minerals precipitated in $\mathrm{MgSO}_{4}$ solutions are shown in Figure 8. It can be seen from Figure 8 $\mathrm{a}_{1}$ and $\mathrm{a}_{2}$ that there are two morphologies of calcite are present, one of which is rhombohedral, whereas the other is spherulitic. The rhombohedral calcite crystals grow in a stepwise manner, with the height of the growth step being approximately $1 \mu \mathrm{m}$. On the other hand, the calcite spherulites, which have very rough surfaces, are approximately $10 \mu \mathrm{m}$ in diameter at an $\mathrm{Mg} / \mathrm{Ca}$ ratio of 0 . Figure $8 \mathrm{~b}_{1}$ shows that the dumbbell-shaped monohydrocalcite crystals, which have a length of approximately $12-15 \mu \mathrm{m}$, are covered with large quantities of hedrite dissipative crystals (Figure $8 \mathrm{~b}_{2}$ ) at an $\mathrm{Mg} / \mathrm{Ca}$ ratio of 2 . The results of EDS analysis of the mineral grains marked with a red square in Figure $8 b_{1}{ }^{\prime}$ show that the main elements include $\mathrm{Ca}, \mathrm{C}$, $\mathrm{O}, \mathrm{Mg}$ and $\mathrm{Al}$ are also present. The $\mathrm{Mg}$ came from the culture medium, and the $\mathrm{Al}$ came from the upholder under the sample. The mineral grains that formed in the medium at an $\mathrm{Mg} / \mathrm{Ca}$ ratio of 4 were dumbbell-shaped and $12-20 \mu \mathrm{m}$ in length (Figure 8c1). Figure 8c2 shows that the surface of the monohydrocalcite is also covered with a large quantity of hedrite dissipative crystals, and these crystals are more regular than those shown in Figure 8b2. The EDS results show that the elemental composition of the mineral grains includes $\mathrm{Ca}, \mathrm{C}, \mathrm{O}$ and small amounts of $\mathrm{Al}$ (Figure 8cí). Figure $8 \mathrm{a} 3$ and a4 shows the micromorphology of the calcite in the experimental group at an $\mathrm{Mg} / \mathrm{Ca}$ ratio of 0 , which illustrates that the LD532 bacteria played an important role in the micromorphological changes. In this figure, the calcite is irregular with an unclear growth step and does not display rhombohedral or spherulitic forms, and their rougher surfaces are covered with different sizes of irregular bulk crystals that are obviously different from those seen in the control group. The mineral grains that precipitate in the culture medium at an $\mathrm{Mg} / \mathrm{Ca}$ molar ratio of 2 display primarily cauliflower-shaped forms (Figure $8 \mathrm{~b}_{3}$ ), and their surfaces are composed of particulate crystals (Figure 8b4). The elemental composition of the minerals includes $\mathrm{Ca}, \mathrm{C}, \mathrm{O}$ and small amounts of $\mathrm{Mg}, \mathrm{Al}, \mathrm{Na}$ and $\mathrm{P}$ (Figure $8 \mathrm{~b}^{\prime}$ ). The $\mathrm{P}$ may have come from the LD532 bacteria. The crystals are elliptical at an $\mathrm{Mg} / \mathrm{Ca}$ molar ratio of 4 (Figure $8 \mathrm{c} 3$ ), and the surface is covered with many 
flaky mineral grains with regular geometric shapes (Figure $8 \mathrm{c}_{4}$ ). The EDS results show that the elemental composition of these grains includes $\mathrm{Ca}, \mathrm{C}, \mathrm{O}$ and small amounts of $\mathrm{Mg}, \mathrm{Al}, \mathrm{Na}$ and $\mathrm{P}$ (Figure 8c ${ }^{\prime}$ ). It can be seen from Figure 8 that there are significant differences in the morphology and elemental composition of the mineral grains that precipitated in the control and experimental group, indicating that the LD532 bacteria played a vital role in the biomineralization process.
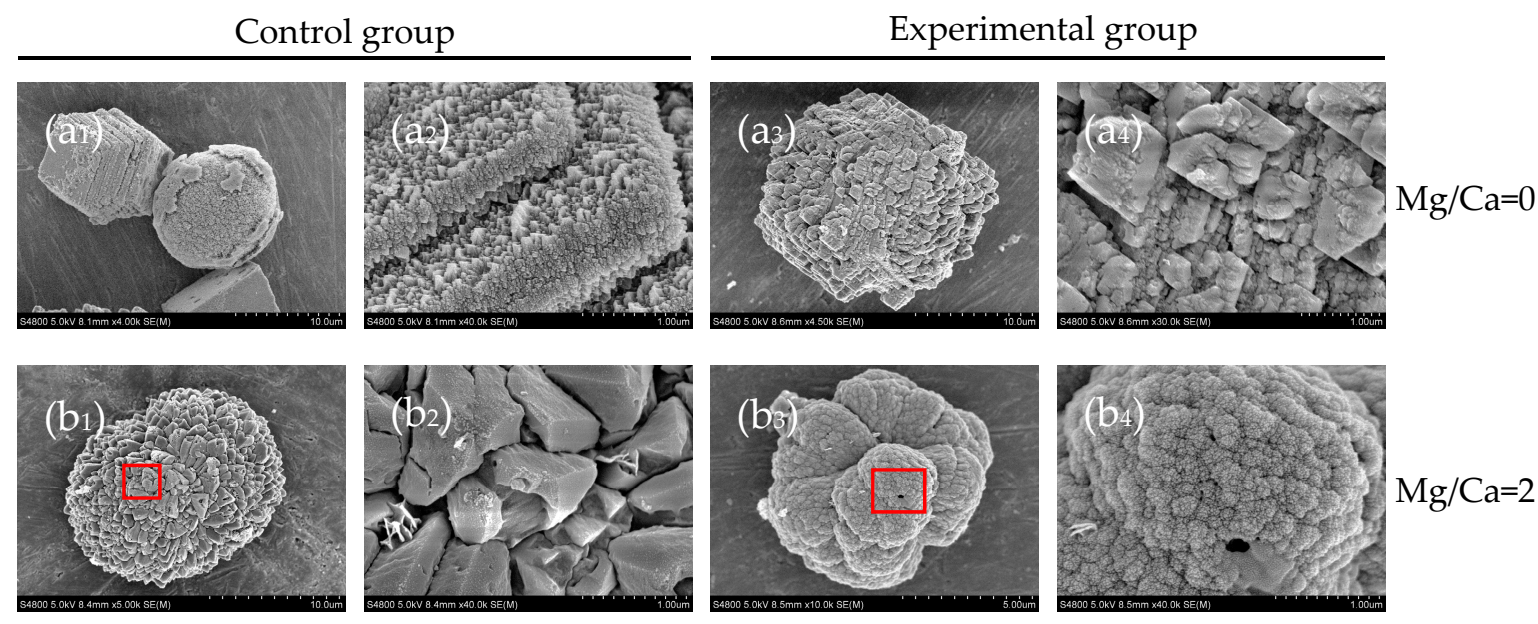

$\mathrm{Mg} / \mathrm{Ca}=2$
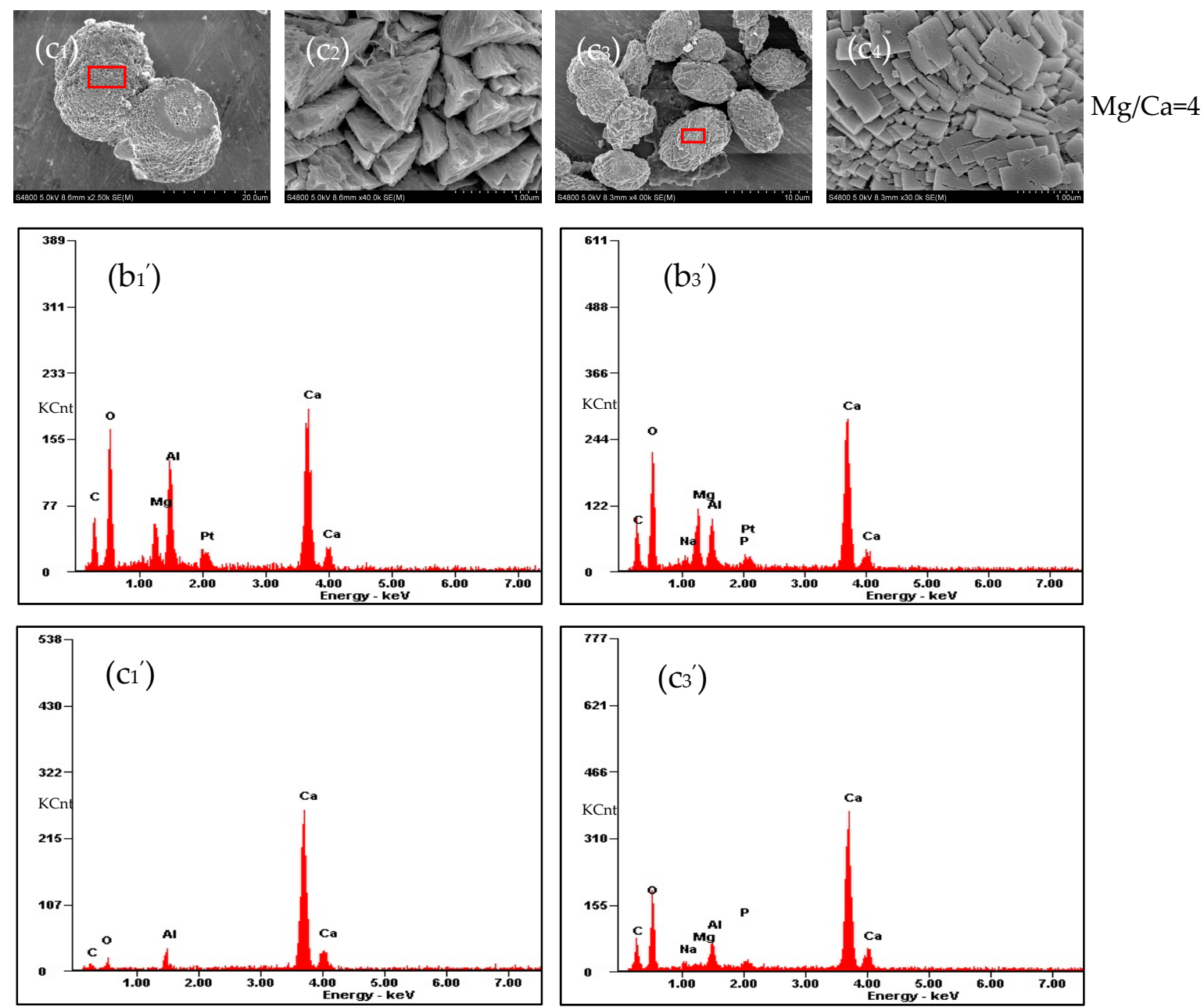

Figure 8. SEM and EDS images of the minerals in control and experimental groups at $15 \% \mathrm{NaCl}$ and different $\mathrm{Mg} / \mathrm{Ca}$ molar ratios in $\mathrm{MgSO}_{4}$ solution after 15 days of cultivation. (a1), (a2) $\mathrm{Mg} / \mathrm{Ca}$ molar ratio of 0 in the control group; ( $\left.b_{1}\right),\left(b_{2}\right) \mathrm{Mg} / \mathrm{Ca}$ molar ratio of 2 in the control group; (c1), (c2) Mg/Ca molar ratio of 4 in the control group; (a3), (a4) Mg/Ca molar ratio of 0 in the experimental group; (b $\left.b_{3}\right)$, (b4) Mg/Ca molar ratio of 2 in

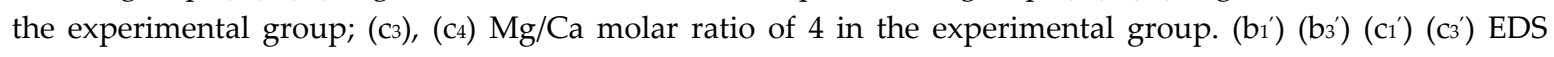
analysis of the mineral marked by the red square, respectively. 
Figure 9 shows the micromorphologies of mineral grains formed in the media with different concentrations of $\mathrm{MgCl}_{2}$. The calcites at an $\mathrm{Mg} / \mathrm{Ca}$ molar ratio of 0 are made up of a large number of irregular rhombohedral crystals with diameters of $5-8 \mu \mathrm{m}$ (Figure 9a1), and the surfaces of the calcites are composed of nanoscale particles (Figure 9a2). The monohydrocalcite spherules are $8-12$ $\mu \mathrm{m}$ in diameter at an $\mathrm{Mg} / \mathrm{Ca}$ molar ratio of 2 (Figure $9 \mathrm{~b}_{1}$ ) and are composed of a large number of fibrous mineral crystals (Figure $9 b_{2}$ ). EDS analysis shows that the elemental composition of this mineral includes $\mathrm{C}, \mathrm{O}$, and $\mathrm{Ca}$ and small amounts of $\mathrm{Mg}$, $\mathrm{Al}$ and $\mathrm{Pt}$ (Figure 9bi'). Pt originated from the spraying operation performed during the sample preparation process. The dumbbell-shaped monohydrocalcite shown in Figure $9 \mathrm{c}$, which is $15-20 \mu \mathrm{m}$ in length, is covered with a large quantity of hedrite dissipative crystals (Figure 9c2) that are smaller than those that occur in the $\mathrm{MgSO}_{4}$ medium. EDS results show that the elemental composition of this mineral includes $\mathrm{Ca}, \mathrm{C}, \mathrm{O}$ and small amounts of $\mathrm{Mg}, \mathrm{Al}$, and $\mathrm{Na}$ (Figure 9 $\mathrm{c}^{\prime}$ ). In the experimental group, the bunchy calcite, approximately $5-10 \mu \mathrm{m}$ in length, that occurs at an $\mathrm{Mg} / \mathrm{Ca}$ molar ratio of 0 and can be seen in Figure 9a3, is composed of countless smaller rhombohedral calcite crystals (Figure 9a4). Cross-shaped mineral grains are observed in Figure 9b3 (marked with the yellow arrows) that are approximately $5 \mu \mathrm{m}$ in length. EDS result shows that the elemental composition of this mineral includes $\mathrm{Al}, \mathrm{Ca}, \mathrm{C}, \mathrm{O}, \mathrm{Mg}$, and $\mathrm{P}$ (Figure $9 \mathrm{~b}_{3}{ }^{\prime}$ ). The mineral grains are mainly cauliflower and dumbbell-shaped in the culture medium at an $\mathrm{Mg} / \mathrm{Ca}$ molar ratio of 2 , and the sizes are in the range of $5-8 \mu \mathrm{m}$ (Figure $9 \mathrm{~b}_{4}$ ). The crystals formed in the culture medium at $\mathrm{Mg} / \mathrm{Ca}$ molar ratio of 4 are dumbbell-shaped and the sizes are approximately $5 \mu \mathrm{m}$ in length (Figure 9c3). The micromorphology of this mineral shown in Figure $9 \mathrm{c}_{4}$ is proved that the surface is covered with a large quantity of microcrystals. EDS results show that the elemental composition of this mineral includes $\mathrm{Ca}, \mathrm{C}, \mathrm{O}, \mathrm{Mg}$, $\mathrm{Al}$, and $\mathrm{P}$ (Figure 9 $\mathrm{c}^{\prime}$ ). From the above result, it could be concluded that there were significant differences in the morphology and elemental composition of the mineral grains between the control and experimental groups.

A comparison of the morphology and elemental composition of the mineral grains between in the $\mathrm{MgSO}_{4}$ solutions and in the $\mathrm{MgCl}_{2}$ solutions shows that different sources of $\mathrm{Mg}^{2+}$ affect the surface micromorphology and the elemental composition of the minerals, and differences were also seen in the different mineral phases formed as a result of the biomineralization processes associated with the LD532 bacteria.

At the same time, the bacteria were not observed on the surfaces of mineral grains shown in the SEM images displayed in Figure 8 and Figure 9.

3.6. Nucleation Sites of Minerals on the EPS of C. israelensis LD532 Bacteria

To determine the nucleation sites of the carbonate minerals, $C$. israelensis LD532 bacteria in aqueous solutions of $\mathrm{MgSO}_{4}$ and $\mathrm{MgCl}_{2}$ were analysed with HRTEM. Figure 10a1 shows the micromorphology of the C. israelensis LD532 bacteria, indicating that the cell surfaces were covered with different sizes of particulates. It can be seen from Figure $10 b_{1}$ and $c 1$ that these particulates have a definite crystal structure, based on the halo ring and the bright spot seen in the SAED spectrum, and they are $\mathrm{NaCl}$ crystals, as determined from the EDS analysis. Only minor amounts of the elements $\mathrm{Mg}$ and $\mathrm{Ca}$ have been measured in the surface of C. israelensis LD532 bacteria, indicating that EPS may have provided the nucleation sites for these carbonate minerals in aqueous solutions of $\mathrm{MgSO}_{4}$ and $\mathrm{MgCl}_{2}$. Figure $10 \mathrm{a}_{2}$ and $\mathrm{b}_{2}$ shows that large quantities of microcrystals cover the EPS, but Figure 10c2 shows that these microcrystals are mainly composed of the elements $\mathrm{Na}$ and $\mathrm{Cl}$, only minor amounts of $\mathrm{Mg}$ and $\mathrm{Ca}$, and therefore the minerals on the EPS were mainly $\mathrm{NaCl}$; small amounts of carbonate minerals may also have occurred.

To further characterize the nucleation sites of the carbonate minerals, ultra-thin slices of $C$. israelensis LD532 bacteria grown in aqueous solutions of $\mathrm{MgSO}_{4}$ and $\mathrm{MgCl}_{2}$ were prepared and observed by TEM. The results are shown in Figure 11. Figure 11 $\mathrm{a}_{1}-\mathrm{c}_{1}$ show images of the ultra-thin slices of $C$. israelensis $\mathrm{LD} 532$ bacteria grown in solutions of $\mathrm{MgSO}_{4}$, and Figure $11 \mathrm{a}_{2}-\mathrm{C}_{2}$ show images of the ultra-thin slices of $C$. israelensis LD532 bacteria grown in solutions of $\mathrm{MgCl}_{2}$. It could be seen from Figure 11 that mineral grains having a size of dozens of nanometers formed in the EPS and inside the cells (marked with yellow arrows), indicating that both intracellular and extracellular 
Control group
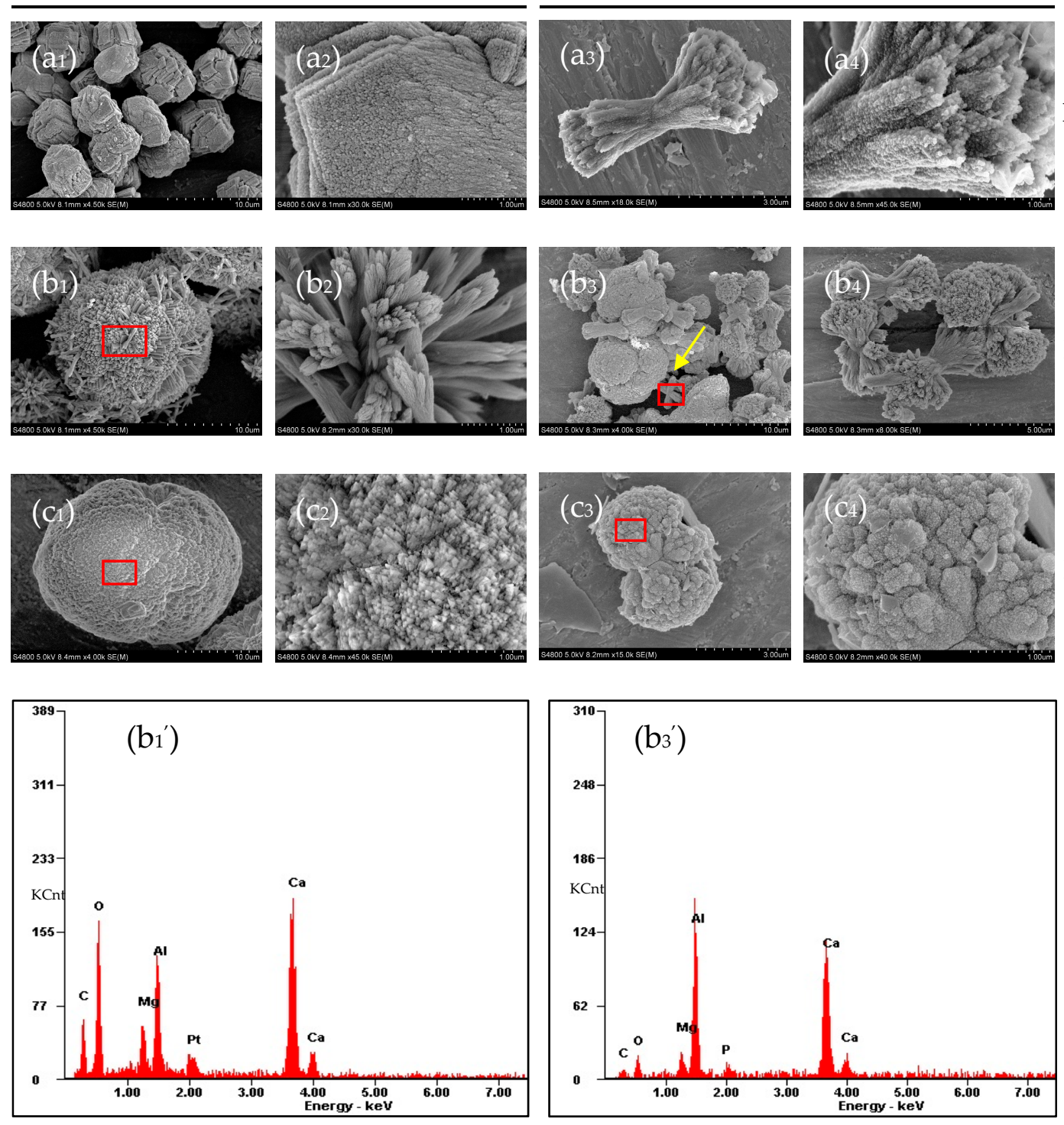

$\mathrm{Mg} / \mathrm{Ca}=0$

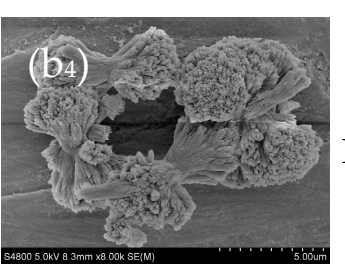

$\mathrm{Mg} / \mathrm{Ca}=2$
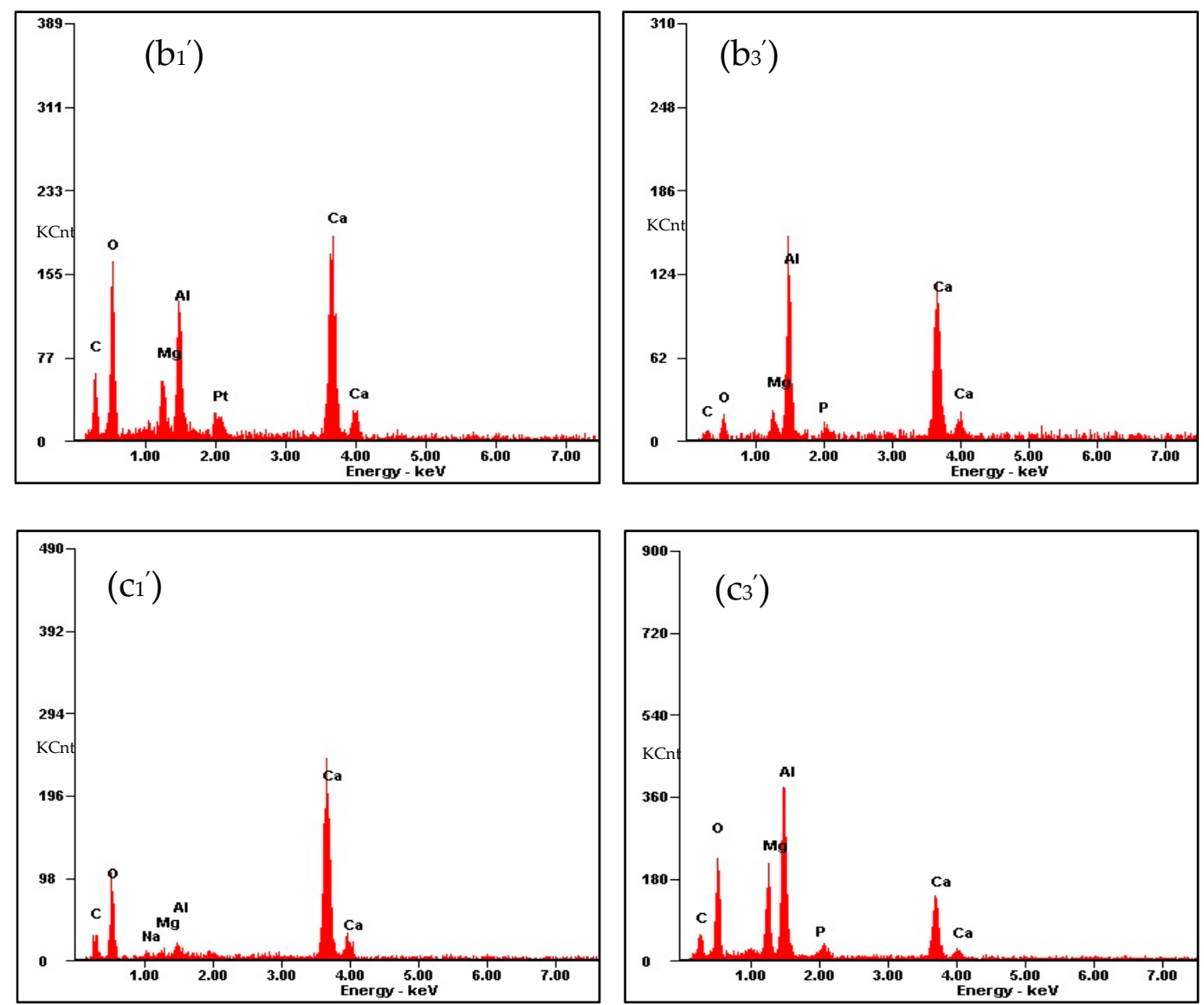

Figure 9. SEM and EDS images of the minerals in the control and experimental groups at $15 \% \mathrm{NaCl}$ and different $\mathrm{Mg} / \mathrm{Ca}$ molar ratios in $\mathrm{MgCl}_{2}$ solution after 15 days of cultivation. (a1), (a2) $\mathrm{Mg} / \mathrm{Ca}$ molar ratio of 0 in the control group; (b1), (b2) Mg/Ca molar ratio of 2 in the control group; (c1), (c2) Mg/Ca molar ratio of 4 in the control group; (a3), (a4) Mg/Ca molar ratio of 0 in the experimental group; (b3), (b4) Mg/Ca molar ratio of 2 in the experimental group; (c3), (c4) Mg/Ca molar ratio of 4 in the experimental group; (b $\left.{ }_{1}^{\prime}\right)\left(\mathrm{b}_{3}{ }^{\prime}\right)\left(\mathrm{c}_{1}^{\prime}\right)$ ( $\left.\mathrm{c}_{3}^{\prime}\right)$ EDS analysis by the red square, respectively. 

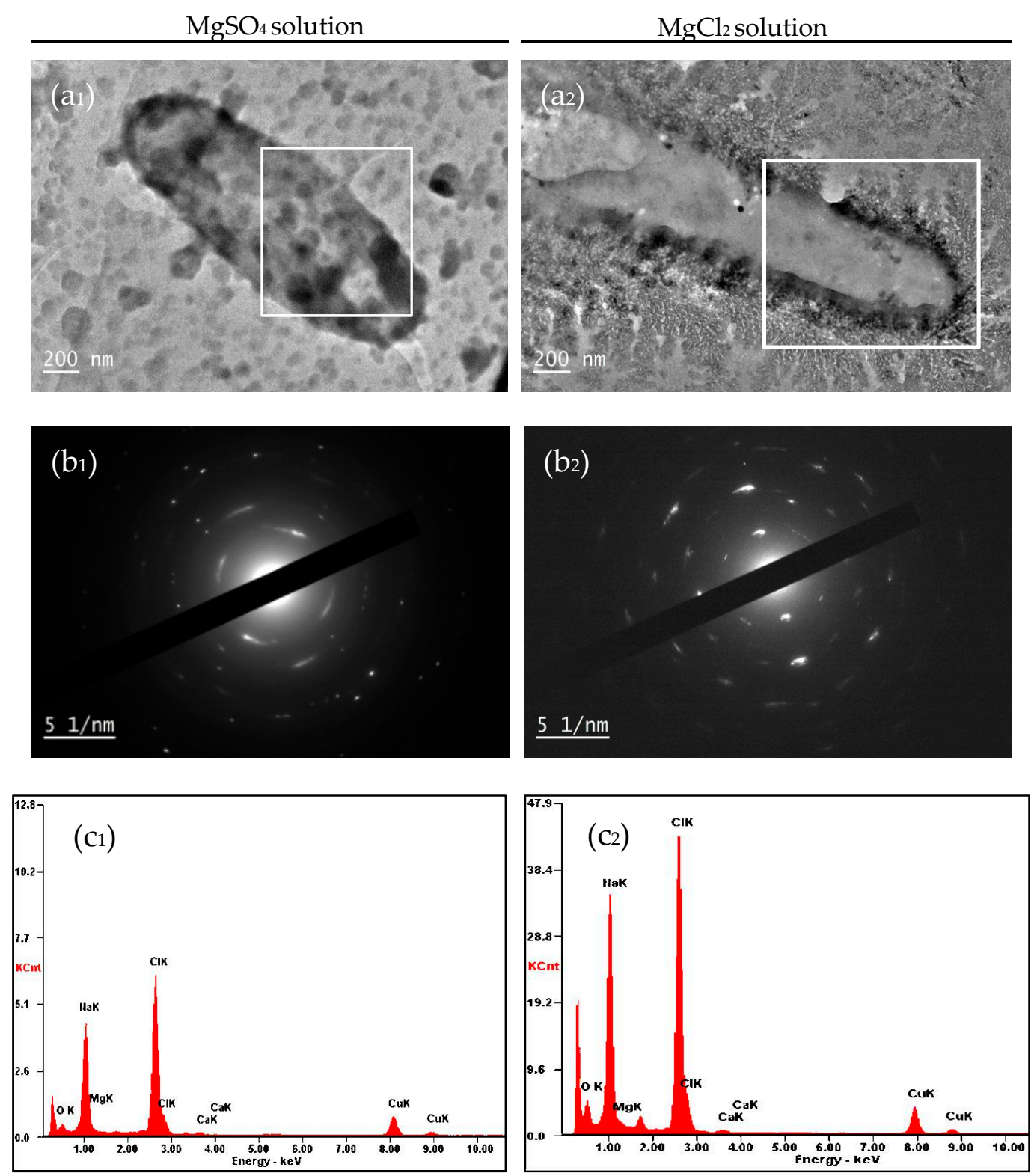

Figure 10. HRTEM, SAED, EDS analysis of the LD532 bacteria cell. (a1) HRTEM analysis of the LD532 bacteria cell at an $\mathrm{Mg} / \mathrm{Ca}$ ratio of 2 in $\mathrm{MgSO}_{4}$ solution; (b1) and (c1) SAED and EDS analysis of the LD532 bacteria cell marked by the white square; (a2) HRTEM analysis in experimental group of $\mathrm{Mg} / \mathrm{Ca}=2$ in aqueous solution of $\mathrm{MgCl}_{2}$; ( $\left.\mathrm{b}_{2}\right)$ and ( $\mathrm{c}_{2}$ SAED and EDS analysis of the LD532 bacteria cell marked by the white square.

carbonate minerals could form. These minerals were identified as carbonates because $\mathrm{NaCl}$ crystals could not form inside the cells of halophilic bacteria, and any $\mathrm{NaCl}$ would have been washed away during the preparation of ultra-thin slices. From the above results, it can be concluded that the nucleation sites of carbonate minerals were located on the EPS and the membrane of intracellular vesicles of $\mathrm{C}$. israelensis $\mathrm{LD} 532$ bacteria in the $\mathrm{MgSO}_{4}$ and $\mathrm{MgCl}_{2}$ solutions.

\section{Discussion}

\subsection{The biological activity of bacteria affects biomineralization}

Different types of microorganisms can release enormous amounts of CA and urease via metabolism, and such releases can change the ambient $\mathrm{pH}$ values in appropriate surroundings $[42,43]$. The activity of CA and urease has been found in a wide range of microorganisms and plants [44]. CA and urease produced by bacterial metabolic activity also play an extremely important role in the biomineralization process $[21,22,43,45]$ because they can increase the $\mathrm{pH}$ values in the culture medium, thus providing prerequisite conditions for the precipitation of minerals. In this work, CA and urease secreted by $C$. israelensis LD532 bacteria were also found. CA is a ubiquitous metalloenzyme that can catalyse the reversible hydration reaction of $\mathrm{CO}_{2}$ [21]. CA can eliminate 
dynamic obstacles and plays an important catalytic role in promoting the conversion of inorganic carbon [46]. The conversion between $\mathrm{CO}_{2}$ and $\mathrm{HCO}_{3}{ }^{-}$can be catalysed by this enzyme, and the conversion formula is as follows:

$$
\mathrm{CO}_{2}+\mathrm{H}_{2} \mathrm{O} \leftrightarrow \mathrm{HCO}_{3}^{-}+\mathrm{H}^{+}
$$
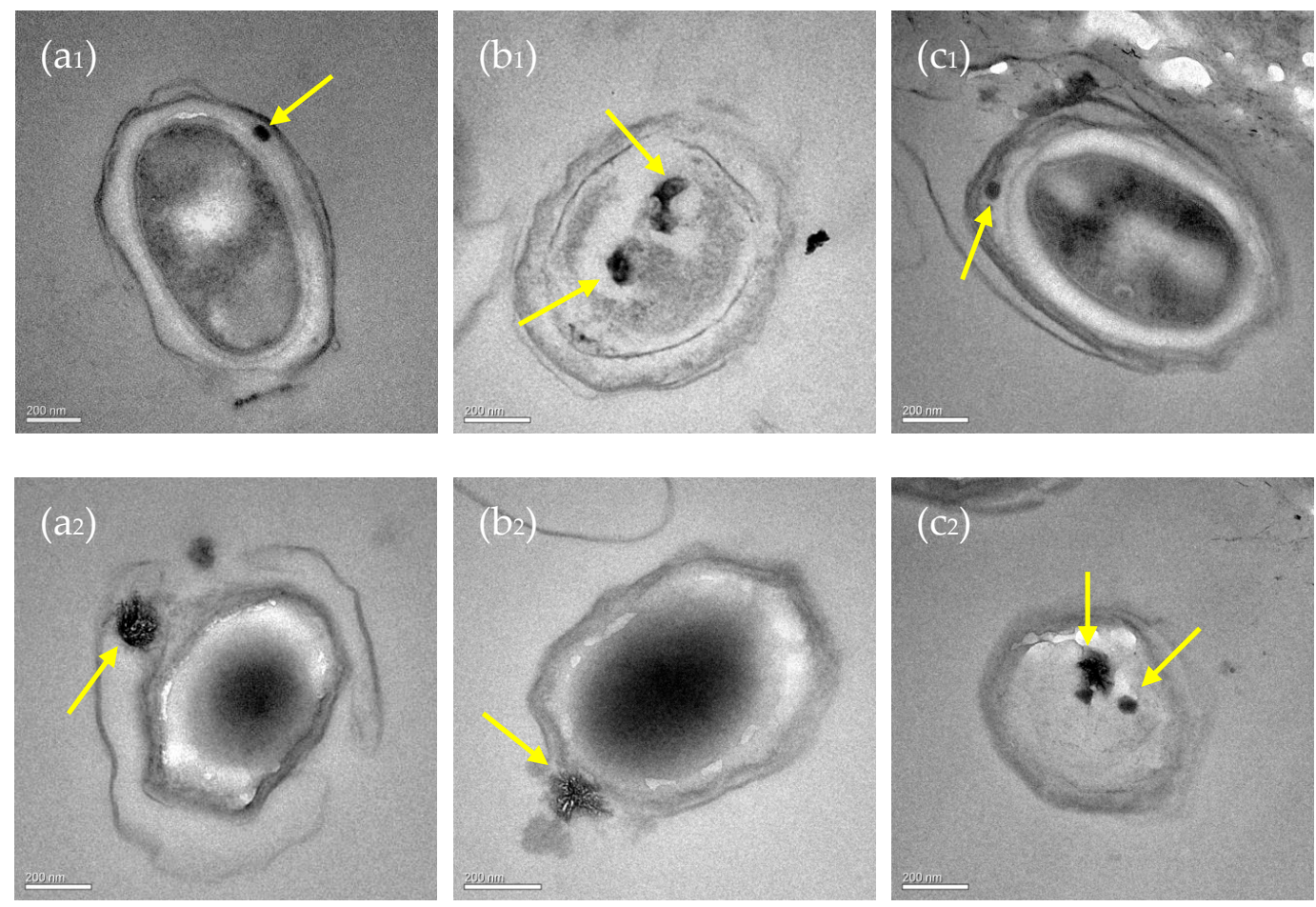

Figure 11. TEM images of ultrathin slices of LD532 bacteria cell after 30 days of culture. (a1), (b1) and (c1) cells at an $\mathrm{Mg} / \mathrm{Ca}$ ratio of 2 in $\mathrm{MgSO}_{4}$ solution; ( $\left.\mathrm{a}_{2}\right)$, ( $\left.\mathrm{b}_{2}\right)$ and ( $\mathrm{c}_{2}$ ) cells at an $\mathrm{Mg} / \mathrm{Ca}$ ratio of 2 in $\mathrm{MgCl}_{2}$ solution. The intracellular and extracellular of minerals are marked with yellow arrows.

Inorganic carbon existed in the form of carbon dioxide in the acidic solution, but it was present in the form of bicarbonate and carbonate under alkaline conditions. More importantly, higher CA activity was noted in alkaline solutions ( $\mathrm{pH}$ values of approximately 8.8 ), as shown in Figures $3 \mathrm{~b}$ and c, indicating that more and more bicarbonate was released to facilitate the following chemical reaction:

$$
\mathrm{Ca}^{2+}+2 \mathrm{HCO}_{3}^{-} \rightarrow \mathrm{CaCO}_{3} \downarrow+\mathrm{H}_{2} \mathrm{O}+\mathrm{CO}_{2} \uparrow
$$

$\mathrm{CA}$ plays an important role in the biomineralization of carbonate. CA occurs widely and participates in the process of converting $\mathrm{CO}_{2}$ to $\mathrm{HCO}_{3}$, acid and ion transport, and cellular $\mathrm{pH}$ regulation as part of calcification and biomineralization [44]. The CA enzyme catalyses the reversible hydration of $\mathrm{CO}_{2}$ to bicarbonate, which may explain its possible relation to carbonate precipitation induced by $H$. anticariensis [31]. Moreover, CA promoted the biomineralization of calcium carbonate in this experiment.

In this study, the physiological and biochemical identification experiments show that urease can be secreted by LD532 bacteria (Table 1). Urease belongs to the superfamily of amidohydrolase and phosphotriesterase, and it can catalyse the hydrolysis of urea into carbon dioxide and ammonia. The reaction occurs as follows:

$$
\left(\mathrm{NH}_{2}\right)_{2} \mathrm{CO}+\mathrm{H}_{2} \mathrm{O} \rightarrow \mathrm{CO}_{2} \uparrow+2 \mathrm{NH}_{3} \uparrow
$$

More specifically, urea can be hydrolysed under the catalyzing effect of urease to produce ammonia and carbamate, and the carbamate is quickly degraded to release another ammonia and carbonic acid. According to the following equation (4), it can be concluded that urease activity tends to increase the $\mathrm{pH}$ of its environment, given that it produces ammonia.

$$
\mathrm{NH}_{3}+\mathrm{H}_{2} \mathrm{O} \rightarrow \mathrm{NH}_{4}^{+}+\mathrm{OH}^{-}
$$

The increase in $\mathrm{pH}$ values shown in Figure $4 \mathrm{c}$ are due to the reaction shown above. The 
carbonic acid produced could be converted to $\mathrm{HCO}_{3}-$ under alkaline conditions, given the catalyzing effect of CA. Therefore, the following chemical reaction (5) occurred in the solution:

$$
\mathrm{Ca}^{2+}+\mathrm{HCO}_{3}^{-}+\mathrm{OH}^{-} \rightarrow \mathrm{CaCO}_{3} \downarrow+\mathrm{H}_{2} \mathrm{O}
$$

Our experimental conclusions indicate that the alkaline condition that formed in the culture medium is a prerequisite for the biomineralization of calcium carbonate. They are also consistent with previous results [4,47]. According to the reaction above, it can easily be seen that the chemical process of calcium carbonate precipitation occurred mainly through reaction (5), indicating that CA and urease activity played a key role in the process of carbonate precipitation.

\subsection{Influence of $\mathrm{Mg}^{2+}$ Source, Concentration and Bacterial Strain on Carbonate Minerals}

\subsubsection{Carbonate Minerals in $\mathrm{MgSO}_{4}$ and $\mathrm{MgCl}_{2}$ solutions}

In this study, the minerals $\mathrm{Mg}$-calcite and monohydrocalcite were produced in the experimental group with an $\mathrm{Mg} / \mathrm{Ca}$ molar ratio of 2 in $\mathrm{MgSO}_{4}$ solutions, whereas only the mineral monohydrocalcite was observed in the control group. The minerals $\mathrm{Mg}$-calcite and a small quantity of aragonite were noted at the same $\mathrm{Mg} / \mathrm{Ca}$ molar ratio in $\mathrm{MgCl}_{2}$ solution in the experimental group, whereas only the mineral monohydrocalcite was seen in the control group. Many researchers have confirmed that bacteria can modify the chemical composition of the culture medium and create microenvironments that favour the precipitation of carbonate minerals $[20,48,49]$. The mineral phases that were observed in these two experimental groups were different (Figures $5 b$ and $6 b$ ) because the bacteria experienced different growth environments, which were solutions of $\mathrm{MgSO}_{4}$ and solutions of $\mathrm{MgCl}_{2}$. It has been reported that $\mathrm{Mg}^{2+}$ can damage the crystal structure of calcite because $\mathrm{Ca}$ atoms can be replaced by $\mathrm{Mg}$ atoms. Therefore, the (104) diffraction peak of calcite moved to the right, as shown in Figures $5 \mathrm{~b}$ and $6 \mathrm{~b}$, and Mg-calcite formed. The formation of Mg-calcite in $\mathrm{MgSO}_{4}$ and $\mathrm{MgCl}_{2}$ solutions with an $\mathrm{Mg} / \mathrm{Ca}$ molar ratio of 2 occurred according to the above principle. On the other hand, another mineral, aragonite, formed in $\mathrm{MgCl}_{2}$ solutions but not $\mathrm{MgSO}_{4}$ solutions, perhaps because the calcite dissolved and recrystallized in the $\mathrm{MgCl}_{2}$ solutions. The formation of ion pairs between $\mathrm{SO}_{4}{ }^{2-}$ and $\mathrm{Mg}^{2+}$ may have reduced the replacement of $\mathrm{Ca}$ atoms by $\mathrm{Mg}$ atoms, which resulted in the dissolution and recrystallization of calcite in the $\mathrm{MgSO}_{4}$ solutions, and therefore no aragonite crystals formed. Based on the above analysis, it can be seen that the different sources of $\mathrm{Mg}^{2+}$ and the LD532 bacteria played very important roles in the formation of new minerals during the biomineralization process.

\subsubsection{Morphology of Carbonate Minerals}

Combined with the XRD and FTIR analyses, Mg-rich calcite and small amounts of aragonite formed in the experimental group with an $\mathrm{Mg} / \mathrm{Ca}$ molar ratio of 2 in $\mathrm{MgCl}_{2}$ solutions, while monohydrocalcite formed in the control group. Important differences were observed in the morphology of mineral surfaces formed between the experimental group and the control group (Figure $\left.9 b_{1}, b_{2}, b_{3}, b_{4}\right)$. The organic macromolecules of organisms play an important role in regulating and controlling the formation of the unique morphology of the minerals in the mineralization process [39]. Organic functional groups have some influence on the morphology of calcite [50]. In our experimental study, the organic functional groups, such as $\mathrm{O}-\mathrm{H}, \mathrm{C}=\mathrm{O}, \mathrm{C}-\mathrm{H}$ methylene and $\mathrm{C}-\mathrm{H}$ methyl (Figure $7 \mathrm{a}$ and $\mathrm{b}$ ), played an important role in changing the morphology of the minerals.

The morphology of monohydrocalcite induced by different strains and different conditions was variable. In our research, the morphology of monohydrocalcite induced by $C$. israelensis LD532 bacteria was also different under different growth conditions (Figures 8 and 9). The monohydrocalcite that formed in $\mathrm{MgSO}_{4}$ solutions (Figure $8 \mathrm{~b}_{1}$ and $\mathrm{c}_{1}$ ) was mainly dumbbell-shaped, and the surfaces were also covered with large quantities of regular or irregular hedrite dissipative crystals; however, the monohydrocalcite that formed in $\mathrm{MgCl}_{2}$ solutions (Figure $9 \mathrm{~b}_{1}$ and $\mathrm{c}_{1}$ ) was mainly spherulitic and elliptical, and the surface was composed of a large number of fibrous mineral crystals and smaller hedrite dissipative crystals. $\mathrm{Mg}^{2+}$ plays a very important role in the formation process of monohydrocalcite. Many researchers have reported that $\mathrm{Mg}$ is ubiquitous in the formation of monohydrocalcite in both laboratory experiments and natural environments [51,52], and a high content of $\mathrm{Mg}$ in the culture medium is a prerequisite for its formation [53]. It is 
clear that the difference in mineral morphology is caused by the different sources of $\mathrm{Mg}^{2+}$ because the bacteria are not present, and the other conditions were the same as those in the process of biomineralization. The morphology of calcite and monohydrocalcite induced by $C$. israelensis LD532 bacteria was also different for the same $\mathrm{Mg} / \mathrm{Ca}$ molar ratio and sources of $\mathrm{Mg}^{2+}$ in the experimental groups, indicating that the biological activity of bacteria can alter the morphology of the mineral surfaces.

In this study, it was concluded that the surface morphology of the mineral grains induced by $C$. israelensis LD532 bacteria had changed, new mineral phases appeared during the process of biomineralization, and $\mathrm{Mg} / \mathrm{Ca}$ ratios and the source of $\mathrm{Mg}^{2+}$ in the solution controlled the crystal morphology of the mineral grains, as well as their composition.

4.3. The Formation of Aragonite in the Presence of C. israelensis LD532 Bacteria

The combination of XRD (Figure 6b) and SEM (Figure 9b3) results shows that aragonite was produced when the $\mathrm{Mg} / \mathrm{Ca}$ molar ratio is 2 in the experimental group containing $\mathrm{MgCl}_{2}$ solution, whereas aragonite was not produced in the control group. The result of EDS shows that the elemental composition of the aragonite includes $\mathrm{Al}, \mathrm{Ca}, \mathrm{C}, \mathrm{O}, \mathrm{Mg}$, and $\mathrm{P}$ (Figure 9b3'). The $\mathrm{Al}$ came from the upholder under the sample, the $\mathrm{Mg}$ was derived from the culture medium, and the $\mathrm{P}$ may have been derived from the LD532 bacteria. The shape of the aragonite formed in this study was consistent with cross-shaped aragonite observed using a polarizing microscope [54]. It has been reported that $\mathrm{Mg}^{2+}$ can hardly be detected in non-biogenic aragonite minerals [55] because $\mathrm{Mg}^{2+}$ does not enter the orthorhombic aragonite lattice, however, aragonite formed by biological processes often contains $\mathrm{Mg}^{2+}$. The elemental composition of the aragonite observed in this study contained $\mathrm{Mg}^{2+}$, as determined using EDS, indicating that the $\mathrm{Mg}^{2+}$ may combine with the bacteria to make more $\mathrm{Mg}^{2+}$ aragonite. In other words, C. israelensis LD532 bacteria have an important controlling effect on the content of $\mathrm{Mg}^{2+}$ in aragonite.

\subsection{Intracellular and Extracellular Nucleation of Carbonate Minerals}

Bacteria can change their ambient environments [28] and provide nucleation sites by adsorbing $\mathrm{Ca}^{2+}, \mathrm{Mg}^{2+}$ and other metallic cations onto EPS, membranes and walls $[24,56]$ in the formation process of minerals. The EPS produced by bacteria not only plays a vital role in the overall ionic charges, it also serves as a nucleation site during the process of calcification [44]. It can be seen from Figure 11 that biomineralization can occur in the intracellular and extracellular LD532 bacteria, indicating that the nucleation sites occurred on the EPS and the membranes of intracellular vesicles. Bacteria can serve as a nucleus for carbonate mineral precipitation by adsorbing cations around their EPS [23]. The formation and structures of carbonate crystals induced by methanogenic archaea are controlled by the cell walls and EPS [57]. EPS plays an important role in the complex process of bacterial adhesion to minerals [58]. Meanwhile, our experimental results were consistent with the above conclusions. EPS are mostly composed of polysaccharides (exopolysaccharides) and proteins, but they also include other macro-molecules such as DNA, lipids and humic substances [59], specialized measures are required in order to identify and quantify EPS substances definitively [60]. In this study, the $\mathrm{pH}$ values were above 7.3 at the start of cultivation and increased with incubation time, as shown in Figure 4c, indicating that biomacromolecules such as proteins and DNA were negatively charged in the alkaline environment. Therefore, the positively charged $\mathrm{Ca}^{2+}$ and $\mathrm{Mg}^{2+}$ could be absorbed on these negatively charged biomacromolecules on the EPS, and nucleation occurred subsequently. The presence of $\mathrm{P}$ in Figure $8 \mathrm{~b}_{3}$ shows that the mineral contained the element $\mathrm{P}$, indicating that there was a close relationship between the bacterially induced minerals and DNA because there were too many phosphate groups in the DNA molecules. Therefore, it could be inferred from Figure $8 \mathrm{~b}_{3}^{\prime}$ and Figure 11 that the nucleation sites of calcium carbonate might occur on the DNA located in the EPS. There have been many important reports that the nucleation sites of bacterially induced minerals are located on the EPS.

It was found that no bacteria were present on the surface of the minerals shown in Figures 8 and 9, which was because the C. israelensis LD532 bacteria were destroyed and lysed during washing with distilled water in the process of sample preparation for SEM. For the halophilic bacteria, $\mathrm{Na}^{+}$has an important role in maintaining the structure and function of cell membranes and 
cell walls [61]. The $\mathrm{Na}^{+}$present on the cytoderm of halophilic bacteria could prevent the cytoderm from lysing and could also protect the negatively charged proteins of these bacterial cells from being damaged. When the amount of $\mathrm{Na}^{+}$was insufficient or became diluted in the solution, the cytoderm would lyse due to the change in osmotic pressure. The negatively charged proteins would then lose their activity, and therefore the halophilic bacteria could not live below a certain concentration of $\mathrm{NaCl}$. Based on the above analysis, the lack of bacteria in the SEM images can be explained.

Studying the formation processes of carbonate minerals at different $\mathrm{Mg} / \mathrm{Ca}$ molar ratios and exploring the mechanism of bacterially induced biomineralization is helpful for explaining their role in ancient biogeochemical cycles and reconstructing palaeoenvironments during geological history. It is also helpful to explain the origin of carbonate rocks in ancient sedimentary environments, and it is of great significance for studying the chemical evolution and early evolution of life in palaeoceanographic environments during Earth's history.

\section{Conclusions}

To study the effect of microbes, mainly halophiles, on the formation of mineral deposits, $C$. israelensis LD532 isolated from the Yinjiashan Saltern in China was used to investigate the biomineralization process of the carbonate minerals at different $\mathrm{Mg} / \mathrm{Ca}$ molar ratios and different sources of $\mathrm{Mg}^{2+}$. The activity of CA and urease played an extremely important role in the process of biomineralization. Both intracellular and extracellular biomineralization occurred LD532 bacteria, and the nucleation sites occurred on the EPS and the membranes of intracellular vesicles. There were significant differences in the phases and morphologies of minerals that formed in $\mathrm{MgSO}_{4}$ solutions and those that formed in $\mathrm{MgCl}_{2}$ solutions, indicating that different sources of $\mathrm{Mg}^{2+}$ could affect the physiological and biochemical activities of microorganisms and thereby affect the mineral deposition.

Acknowledgements: This work was supported by the National Natural Science Foundation of China (41372108, U1663201), The Scientific and Technological Innovation Project Financially Supported by Qingdao National Laboratory for Marine Science and Technology(No. 2016ASKJ13), Open Fund of the Key Laboratory of Marine Geology and Environment, Chinese Academy of Sciences (No. MGE2016KG10), the Specialized Research Fund for the Doctoral Program of Higher Education (20133718130001), and supported by SDUST Research Fund (2015TDJH101), Shandong Provincial Key Laboratory of Depositional Mineralization and Sedimentary Minerals (DMSM201412), Shandong Province Natural Science Foundation (ZR2013DQ005, ZR2014DM005), the China Postdoctoral Science Foundation founded project (2013M540560, 2014T70659, 2016M600548), Qingdao Postdoctoral Applied Research Project (2015199).

Author Contributions: Zuozhen Han conceived and designed the experiments; Dan $\mathrm{Li}$ and Peiyuan Li performed the experiments; Zuozhen Han, Hui Zhao, and Huaxiao Yan analyzed the results of all the experiments; Dan Li and Huaxiao Yan wrote the paper. Hui Zhao revised the manuscript. All authors read and approved the manuscript.

Conflicts of Interest: The authors declare no conflict of interest.

\section{References}

1. Spötl, C.; Fairchild, I.J.; Tooth, A.F. Cave air control on dripwater geochemistry, Obir Caves (Austria): Implications for speleothem deposition in dynamically ventilated caves. Geochim. Cosmochim. Ac. 2005, 69, 2451-2468, DOI: 10.1016/j.gca.2004.12.009.

2. Morita, R.Y. Calcite precipitation by marine bacteria. Geomicrobiol. J. 1980, 2, 63-82, DOI: 10.1016/j.desal.2016.11.027.

3. Ferris, F.G.; Fyfe, W.S.; Beveridge, T.J. Bacteria as nucleation sites for authigenic minerals in a metal-contaminated lake sediment. Chem. Geol. 1987, 63, 225-232, DOI: 10.1016/0009-2541(87)90165-3.

4. Castanier, S.; Le M'etayer-Levrel, G.; Perthuisot, J.P. Ca-carbonate precipitation and limestone genesis-the microbiologist point of view. Sediment Geol. 1999, 126, 9-23, DOI: 10.1016/S0037-0738(99)00028-7.

5. Rivadeneyra, M.A.; Delgado, G.; Ramos-Cormenzana, A.; Delgado, R. Biomineralization of carbonates by Halomonas eurihalina in solid and liquid media with different salinities: crystal formation sequence. Res. Microbiol. 1998, 149, 277-287, DOI: 10.1016/S0923-2508(98)80303-3.

6. Rivadeneyra, M.A.; Párraga, J.; Delgado, R.; Ramos-Cormenzana, A.; Delgado, G. Biomineralization of carbonates by Halobacillus trueperi in solid and liquid media with different salinities. FEMS Microbiol. Ecol. 
2004, 48, 39-46, DOI: 10.1016/j.femsec.2003.12.008.

7. Rivadeneyra, M.A.; Martín-Algarra, A.; Sánchez-Navas, A.; Martín-Ramos, D. Carbonate and phosphate precipitation by Chromohalobacter marismortui. Geomicrobiol. J. 2006, 23, 89-101, DOI: 10.1080/01490450500533882.

8. Rivadeneyra, M.A.; Martín-Algarra, A.; Sánchez-Román, M.; Sánchez-Navas, A.; Martín-Ramos, J.D. Amorphous Ca-phosphate precursors for Ca-carbonate biominerals mediated by Chromohalobacter marismortui. ISME J. 2010, 4, 922-932, DOI: 10.1038/ismej.2010.17.

9. Van Lith, Y.; Warthmann, R.; Vasconcelos, C.; Mckenzie, J.A. Sulphate-reducing bacteria induce low-temperature Ca-dolomite and high Mg-calcite formation. Geobiology 2003, 1, 71-79, DOI: 10.1046/j.1472-4669.2003.00003.x.

10. Sánchez-Román, M.; Rivadeneyra, M.A.; Vasconcelos, C.; McKenzie, J.A. Biomineralization of carbonate and phosphate by moderately halophilic bacteria. FEMS Microbiol. Ecol. 2007, 61, 273-284, DOI: 10.1111/j.1574-6941.2007.00336.x.

11. Ehrlich, H.L. Geomicrobiology 4th Ed (Revised and Expanded). New York: Marcel Dekker Inc 2002.

12. Kranz, S.A.; Wolf-Gladrow, D.; Nehrke, G.; Langer, G.; Rost, B. Calcium carbonate precipitation induced by the growth of the marine cyanobacteria Trichodesmium. Limnol. Oceanogr. 2010, 55, 2563-2569, DOI: 10.4319/lo.2010.55.6.2563.

13. Braissant, O.; Decho, A.W.; Dupraz, C.; Glunk, C.; Przekop, K.M.; Visscher, P.T. Exopolymeric substances of sulfate-reducing bacteria: Interactions with calcium at alkaline $\mathrm{pH}$ and implication for formation of carbonate minerals. Gebiology 2007, 5, 401-411, DOI: 10.1111/j.1472-4669.2007.00117.x.

14. Han, Z.Z.; Zhao, Y.Y.; Yan, H.X.; Zhao, H.; Han, M.; Sun, B.; Sun, X.Y.; Hou, F.F.; Sun, H.;Han, L.;Sun, Y.B.; Wang, J.; Li, H.; Wang, Y.Q.; Du, H. Struvite Precipitation Induced by a Novel Sulfate-Reducing Bacterium Acinetobacter calcoaceticus SRB4 Isolated from River Sediment. Geomicrobiol. J. 2015, 32, 868-877, DOI: 10.1080/01490451.2015.1016247.

15. Ercole, C.; Cacchio, P.; Botta, A.L.; Centi, V.; Lepidi, A. Bacterially induced mineralization of calcium carbonate: the role of exopolysaccharides and capsular polysaccharides. Microsc. Microanal. 2007, 13, 42-50, DOI: $10.1017 / S 1431927607070122$.

16. Han, Z.Z.; Yan, H.X.; Zhou, S.X.; Zhao, H.; Zhang, Y.; Zhang, N.N.; Yao, C.K.; Zhang, L.; Han, C.Y. Precipitation of calcite induced by Synechocystis sp. PCC6803. World J. Microbiol. Biotechnol. 2013, 29, 18011811, DOI: 10.1007/s11274-013-1341-1.

17. Yan, H.X.; Han, Z.Z.; Zhao, H.; Zhou, S.X.; Chi, N.J.; Han, M.; Kou, X.Y. Zhang, Y.; Xu, L.L.; Tian, C.C.; Qin, S. Characterization of calcium deposition induced by Synechocystis sp PCC6803 in BG11 culture medium. Chin. J. Oceanol. Limn. 2014, 32, 503-510, DOI: 10.1007/s00343-014-3150-2.

18. Boquet, E.; Boronat, A.; Ramos-Cormenzana, A. Production of calcite (calcium carbonate) crystals by soil bacteria is a general phenomenon. Nature (Lond) 1973, 246, 527-529, DOI: 10.1038/246527a0.

19. Lowenstam, H.A.; Weiner, S. (eds) On Biomineralization. Oxford University Press, Oxford 1989.

20. Bachmeier, K.L.; Williams, A.E.; Warmington, J.R.; Bang, S.S. Urease activity in microbiologically-induced calcite Precipitation. J. Biotechnol. 2002, 93, 171-181, DOi: 10.1016/S0168-1656(01)00393-5.

21. Dhami, N.K.; Mukherjee, A.; Reddy, M.S. Micrographical minerological and nano-mechanical characterisation of microbial carbonates from urease and carbonic anhydrase producing bacteria. Ecol. Eng. 2016, 94, 443-454, DOI: 10.1016/j.ecoleng.2016.06.013.

22. Lian, B.; Hu, Q.N.; Chen, J.; Ji, J.F.; Teng, H.H. Carbonate biomineralization induced by soil bacterium Bacillus megaterium. Geochim. Cosmochim. Ac. 2006, 70, 5522-5535, DOI: 10.1016/j.gca.2006.08.044.

23. Braissant, O.; Cailleau, G.; Dupraz, C.; Verrecchia, E.P. Bacterially induced mineralization of calcium carbonate in terrestrial environment: the role of exopolysaccharides and amino-acids. J. Sediment. Res. 2003, 73, 485-490, DOI: 10.1306/111302730485.

24. Van Lith, Y.; Warthmann, R.; Vasconcelos, C.; Mckenzie, J.A. Microbial fossilization in carbonate sediments: a result of the bacterial surface involvement in dolomite precipitation. Sedimentology 2003, 50, 237-245, DOI: 10.1046/j.1365-3091.2003.00550.x

25. Rivadeneyra, M.A.; Delgado, R.; Parraga, J.; Ramos-Cormenzana, A.; Delgado, G. Precipitation of Minerals by 22 Species of Moderately Halophilic Bacteria in Artificial Marine Salts Media: Influence of Salt Concentration. Folia. Microbiol. 2006, 51, 445-453, DOI: 10.1007/BF02931589.

26. Taylor, S.R.; Mclennan, S.M. The Continental Crust. Its Evolution and Composition. Oxford: Blackwell Science 1985. 
27. Stanley, S.M.; Ries, J.B.; Hardie, L.A. Low-magnesium calcite produced by coralline algae in seawater of Late Cretaceous composition. P. Natl. Acad .Sci. USA 2002, 99, 15323-15326, DOI: 10.1073/pnas.232569499.

28. Sánchez-Román, M.; Romanek, C.S.; Fernández-Remolar, D.C.; Sánchez-Navas, A.; McKenzie, J.A.; Pibernat, R.A.; Vasconcelos, C. Aerobic biomineralization of Mg-rich carbonates: Implications for natural environments. Chem. Geol. 2011, 281, 143-150, DOI: 10.1016/j.chemgeo.2010.11.020.

29. Rodriguez-Blanco, J.D.; Shaw, S.; Bots, P.; Roncal-Herrero, T.; Benning, L.G. The role of $\mathrm{Mg}$ in the crystallization of monohydrocalcite. Geochim. Cosmochim. Ac. 2014, 127, 204-220, DOI: 10.1016/j.gca.2013.11.034.

30. Ventosa, A.; Gutierrez, M.C.; Garcia, M.T.; Ruiz-Berraquero, F. Classification of “Chomobacterium marismortui" in a New Genus, Chromohalobacter gen.nov., as Chromohalobacter marismortui comb. nov., nom.rev. Inter. J. System. Bacteriol. 1989, 39, 382-386, DOI: 10.1099/00207713-39-4-382.

31. Rivadeneyra, A.; Rivadeneyra, M.A.; Escamilla, C.V.; Algarra, A.M.; Navas, A.S.; Martín-Ramos, J.D. The influence of Salt Concentration on the Precipitation of Magnesium Calcite and Calcium Dolomite by Halomonas Anticariensis. Expert Opi.n Environ. Biol. 2016, DOI: 10.4172/2325-9655.1000130.

32. Deng, S.C.; Dong, H.L.; Lv, G.; Jiang, H.C.; Yu, B.S.; Bishop, M.E. Microbial dolomite precipitation using sulfate reducing and halophilic bacteria: Results from Qinghai Lake, Tibetan Plateau, NW China. Chem. Geol. 2010, 278, 151-159, DOI: 10.1016/j.chemgeo.2010.09.008.

33. Babavalian, H.; Amoozegar, M.A.; Pourbabaee, A.A.; Moghaddam, M.M.; Shakeri, F. Isolation and identification of moderately halophilic bacteria producing hydrolytic enzymes from the largest hypersaline playa in Iran. Microbiology 2013, 82, 466-474, DOI: 10.1134/S0026261713040176.

34. Kim, C.S.; Lee, C.H.; Shin, J.S.; Chung, Y.S.; Hyung, N.I. A simple and rapid method for isolation of high quality genomic DNA from fruit trees and conifers using PVP. Nucl. Acids. Res. 1997, 25, 1085-1086, DOI: 10.1093/nar/25.5.1085.

35. Madhaiyan, M.; Poonguzhali, S.; Kwon, S.W.; Sa, T.M. Methylobacterium phyllosphaerae sp. nov., a pink-pigmented, facultative methylotroph from rice. Int. J. Syst. Evol. Microbiol. 2009, 59, 22-27, DOI: 10.1099/ijs.0.001693-0.

36. Weisburg, W.G.; Barns, S.M.; Pelletier, D.A.; Lane, D.J. 16 S ribosomal DNA amplification for phylogenetic study. J. Bacteriol. 1991, 2, 697-703, DOI: 10.1128/jb.173.2.697-703.1991.

37. Smith, K.S.; Ferry, J.G. A plant-type ( $\beta$-class) carbonic anhydrase in the thermophilic methanoarchaeon Methanobacterium thermoautotrophicum. J Bacteriol 1999, 181, 6247-6253.

38. Goldsmith, J.R.; Graf, D.L.; Heard, H.C. Lattice constants of the calcium-magnesium carbonates. Am. Mineral. 1961, 46, 453-457.

39. Arvidson, R.S.; Mackenzie, F.T. The dolomite problem: Control of precipitation kinetics by temperature and saturation state. Am. J. Sci. 1999, 299, 257-288, DOI: 10.2475/ajs.299.4.257.

40. Guo, C.; Liu, H.Z.; Wang, J.; Chen, J.Y. Conformational structure of triblock copolymers by FT-Raman and FTIR spectroscopy. J. Colloid. Interface. Sci. 1999, 209, 368-373, DOI: 10.1006/jcis.1998.5897.

41. Su, Y.L.; Liu, H.Z.; Guo, C.; Wang, J. Association behavior of PEO-PPO-PEO block copolymers in water or organic solvent observed by FTIR spectroscopy. Mol. Simul. 2003, 29, 803-808, DOI: 10.1080/0892702031000121888.

42. Mobley, H.L.; Island, M.D.; Hausinger, R.P. Molecular biology of microbial ureases. Microbiol. Rev. 1995, 59, 451-480.

43. Achal, V.; Pan, X.L. Characterization of urease and carbonic anhydrase producing bacteria and their role in calcite precipitation. Curr. Microbiol. 2011, 62, 894-902, DOI: 10.1007/s00284-010-9801-4.

44. Ciurli, S.; Marzadori, C.; Benini, S.; Deiana, S.; Gessa, C. Urease from the soil bacterium Bacillus pasteurii: immobilization on Ca-polygalacturonate. Soil. Biol. Biochem. 1996, 28, 811-817, DOI: 10.1016/0038-0717(96)00020-X.

45. Han, Z.Z.; Sun, B.; Zhao, H.; Yan, H.X.; Han, M.; Zhao, Y.Y.; Meng, R.R.; Zhuang, D.X.; Li, D.; Ma, Y.T.; Ma, P.Y.; Pan, J.T. Isolation of Leclercia adcarboxglata Strain JLS1 from the dolostone sample and characterization of its induced struvite minerals. Geomicrobiol. J. 2016, 1-11. doi: 10.1080/01490451.2016.1222469.

46. Han, Z.Z.; Zhao, Y.Y.; Yan, H.X.; Zhao, H.; Han, M.; Sun, B.; Meng, R.R.; Zhuang, D.X.; Li, D.; Gao, W.J.; Du, S.Y.; Wang, X.A.; Fan K.X.; Hu W.Y.; Zhang, M.X. The Characterization of Intracellular and Extracellular Biomineralization Induced by Synechocystis sp. PCC6803 Cultured under Low Mg/Ca Ratios Conditions. Geomicrobiol. J. 2016, 1-12, DOI: 10.1080/01490451.2016.1197986.

47. De Muynck, W.; De Belie, N.; Verstraete, W. Microbial carbonate precipitation in construction materials: A 
review. Ecol. Eng. 2010, 36, 118-136, DOI: 10.1016/j.ecoleng.2009.02.006.

48. Cailleau, G.; Braissant, O.; Dupraz, C.; Aragno, M.; Verrecchia, E.P. Biologically induced accumulation of $\mathrm{CaCO}_{3}$ in orthox soils of Biga. Ivory Coast Catena 2005, 59, 1-17, DOI: 10.1016/j.catena.2004.06.002.

49. Han, Z.Z.; Zhuang, D.X.; Yan, H.X.; Zhao, H.; Sun, B.; Li, D.; Sun, Y.W.; Hu, W.Y.; Xuan, Q.Z.; Chen, J.A.; Xiu, Y. Thermogravimetric and kinetic analysis of thermal decomposition characteristics of microbial calcites induced by cyanobacteria Synechocystis sp. PCC6803. J. Therm. Anal. Calorim. 2017, 1-9(127, 1371-1379). DOI: 10.1007/s10973-016-6026-1.

50. Wang, Y.Y.; Yao, Q.Z.; Zhou, G.T.; Fu, S.Q. Formation of elongated calcite mesocrystals and implication for biomineralization. Chem. Geol. 2013, 360-361, 126-133, DOI: 10.1016/j.chemgeo.2013.10.013.

51. Fukushi, K.; Munemoto, T.; Sakai, M.; Yagi, S. Monohydrocalcite: a promising remediation material for hazardous anions. Sci. Technol. Adv. Mater 2011, 12, 1-12, DOI: 10.1088/1468-6996/12/6/064702.

52. Nishiyama, R.; Munemoto, T.; Fukushi, K. Formation condition of monohydrocalcite from $\mathrm{CaCl}_{2}-\mathrm{MgCl}_{2}-$ $\mathrm{Na}_{2} \mathrm{CO}_{3}$ solutions. Geochim. Cosmochim. Ac. 2013, 100, 217-231, DOI: 10.1016/j.jca.2012.09.002.

53. Kimura, T.; Koga, N. Monohydrocalcite in comparisonwith hydrated amorphous calcium carbonate: precipitation condition and thermal behavior. Cryst. Growth Des. 2011, 11, 3877-3884, DOI: $10.1021 / \mathrm{cg} 200412 \mathrm{~h}$.

54. Han, Z.Z.; Meng, R.R.; Yan, H.X.; Zhao, H.; Han, M.; Zhao, Y.Y.; Sun, B.; Sun, Y.B.; Wang, J.; Zhuang, D.X.; Li, W.J.; Lu, L.X. Calcium carbonate precipitation by Synechocystis sp. PCC6803 at different Mg/Ca molar ratios under the laboratory condition. Carbonate. Evaporite. 2016, 1-15. DOI: 10.1007/s13146-016-0322-5.

55. Porter, S.M. Seawater chemistry and early carbonates biomineralization. Science 2007, 316, 1302, DOI: 10.1126/science.1137284.

56. Bontognali, T.R.R.; Vasconcelos, C.; Warthmann, R.J.; Dupraz, C.; Bernasconi, S.M.; McKenzie, J.A. Microbes produce nanobacteria-like structures, avoiding entombment. Geology 2008, 36, 663-666, DOI: 10.1130/G24755A.1.

57. Kenward, P.A.; Goldstein, R.H.; Gonzalez, L.A.; Roberts, J.A. Precipitation of low-temperature dolomite from an anaerobic microbial consortium: the role of methanogenic Archaea. Geobiology 2009, 7, 556-565, DOI: 10.1111/j.1472-4669.2009.00210.x.

58. Li, Q.; Wang, Q.F.; Zhu, J.Y.; Zhou, S.; Gan, M.; Jiang H.; Sand, W.G. Effect of Extracellular Polymeric Substances on Surface Properties and Attachment Behavior of Acidithiobacillus ferrooxidans. Minerals 2016, 6, 1-11.DOI: 10.3390/min6040100.

59. Sheng, G.P.; Yu, H.Q.; Li, X.Y. Extracellular polymeric substances (EPS) of microbial aggregates in biological wastewater treatment systems: a review. Biotechnol. Adv. 2010, 28, 882-894, DOI: 10.1016/j.biotechadv.2010.08.001.

60. Jaisi, D.P.; Dong, H.L.; Kim, J.W.; He, Z.Q.; Morton, J.P. Nontronite particle aggregation induced by microbial Fe(III) reduction and exopolysaccharide production. Clay. Clay. Miner. 2007, 55, 96-107. DOI: 10.1346/CCMN.2007.0550108.

61. Von Weymarn, N.; Nyyssölä, A.; Reinikainen, T.; Leisola, M.; Ojamo, H. Improved osmotolerance of recombinant Escherichia coli by de novo glycine betaine biosynthesis. Appl. Microbial. Biot. 2001, 55, 214218, DOI: $10.1007 / \mathrm{s} 002530000515$. 